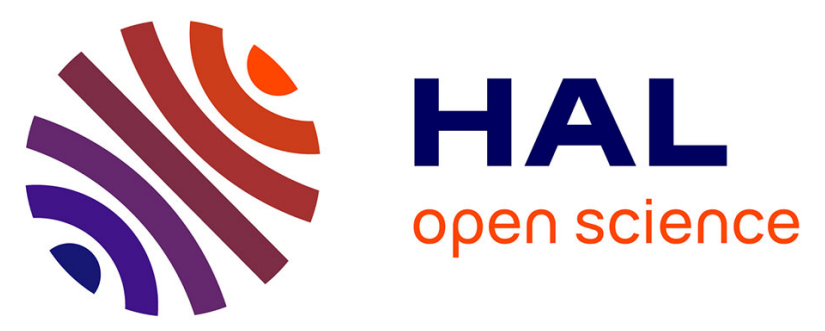

\title{
Is Gold Solubility Subject to Pressure Variations in Ascending Arc Magmas?
}

Sébastien Jégo, Michihiko Nakamura, Jun-Ichi Kimura, Yoshiyuki Iizuka, Qing Chang, Georg F. Zellmer

\section{To cite this version:}

Sébastien Jégo, Michihiko Nakamura, Jun-Ichi Kimura, Yoshiyuki Iizuka, Qing Chang, et al.. Is Gold Solubility Subject to Pressure Variations in Ascending Arc Magmas?. Geochimica et Cosmochimica Acta, 2016, 188, pp.224-243. 10.1016/j.gca.2016.05.034 . insu-01323314

\section{HAL Id: insu-01323314 https://hal-insu.archives-ouvertes.fr/insu-01323314}

Submitted on 30 May 2016

HAL is a multi-disciplinary open access archive for the deposit and dissemination of scientific research documents, whether they are published or not. The documents may come from teaching and research institutions in France or abroad, or from public or private research centers.
L'archive ouverte pluridisciplinaire HAL, est destinée au dépôt et à la diffusion de documents scientifiques de niveau recherche, publiés ou non, émanant des établissements d'enseignement et de recherche français ou étrangers, des laboratoires publics ou privés.

\section{(1) (1) $\$$}

Distributed under a Creative Commons Attribution - NonCommercial - NoDerivatives| 4.0 


\section{Accepted Manuscript}

Is Gold Solubility Subject to Pressure Variations in Ascending Arc Magmas?

Sébastien Jégo, Michihiko Nakamura, Jun-Ichi Kimura, Yoshiyuki Iizuka, Qing Chang, Georg F. Zellmer

PII:

S0016-7037(16)30277-0

DOI: http://dx.doi.org/10.1016/j.gca.2016.05.034

Reference: GCA 9783

To appear in:

Geochimica et Cosmochimica Acta

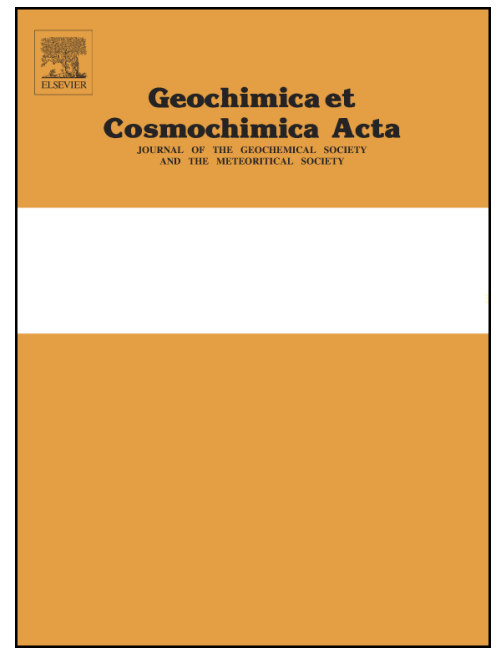

Received Date: $\quad 17$ September 2015

Accepted Date: $\quad 23$ May 2016

Please cite this article as: Jégo, S., Nakamura, M., Kimura, J-I., Iizuka, Y., Chang, Q., Zellmer, G.F., Is Gold Solubility Subject to Pressure Variations in Ascending Arc Magmas?, Geochimica et Cosmochimica Acta (2016), doi: http://dx.doi.org/10.1016/j.gca.2016.05.034

This is a PDF file of an unedited manuscript that has been accepted for publication. As a service to our customers we are providing this early version of the manuscript. The manuscript will undergo copyediting, typesetting, and review of the resulting proof before it is published in its final form. Please note that during the production process errors may be discovered which could affect the content, and all legal disclaimers that apply to the journal pertain. 


\section{Is Gold Solubility Subject to Pressure Variations} in Ascending Arc Magmas?

Sébastien Jégo ${ }^{1,2,}$, Michihiko Nakamura ${ }^{3}$, Jun-Ichi Kimura ${ }^{4}$, Yoshiyuki Iizuka ${ }^{2}$, Qing Chang ${ }^{4}$ and Georg F. Zellmer ${ }^{5}$

${ }^{1}$ Institut des Sciences de la Terre d'Orléans (ISTO) - Université d'Orléans - CNRS: UMR7327

- INSU - Bureau de Recherches Géologiques et Minières (BRGM), France.

${ }^{2}$ Institute of Earth Sciences, Academia Sinica, 128 Academia Road, Sec. 2, Nankang, Taipei 11529, Taiwan, ROC.

${ }^{3}$ Department of Earth Science, Tohoku University, 6-3 Aramaki-Aza-Aoba, Aobaku, Sendai 980-8578, Japan.

${ }^{4}$ Institute for Research on Earth Evolution (IFREE), Japanese Agency for Marine-Earth Science and Technology (JAMSTEC), 15-2 Natsushima-cho, Yokosuka 237-0061, Japan.

${ }^{5}$ Soil and Earth Sciences Group, Massey University, Palmerston North, New Zealand.

* Corresponding author (S. Jego)

E-Mail: Sebastien.Jego@univ-orleans.fr

Phone: +33-2-38-25-53-99 


\section{ABSTRACT}

Magmas play a key role in the genesis of epithermal and porphyry ore deposits, notably by providing the bulk of ore metals to the hydrothermal fluid phase. It has been long shown that the formation of major deposits requires a multi-stage process, including the concentration of metals in silicate melts at depth and their transfer into the exsolved ore fluid in more superficial environments. Both aspects have been intensively studied for most of noble metals in subsurface conditions, whereas the effect of pressure on the concentration (i.e., solubility) of those metals in magmas ascending from the sublithospheric mantle to the shallow arc crust has been quite neglected. Here, we present new experimental data aiming to constrain the processes of gold $\mathrm{Au}$ ) dissolution in subduction-linked magmas along a range of depth. We have conducted hydrous melting experiments on two dacitic/adakitic magmas at 0.9 and 1.4 GPa and $\sim 1000^{\circ} \mathrm{C}$ in an end-loaded piston cylinder apparatus, under $f \mathrm{O}_{2}$ conditions close to NNO as measured by solid Co-Pd-O sensors. Experimental charges were carried out in pure Au containers, the latter serving as the source of gold, in presence of variable amounts of $\mathrm{H}_{2} \mathrm{O}$ and, for half of the charges, with elemental sulfur (S) so as to reach sulfide saturation. Au concentrations in melt quenched to glass were determined by LA-ICPMS. When compared to previous data obtained at lower pressures and variable redox conditions, our results show that in both S-free and sulfide-saturated systems pressure has no direct, detectable effect on melt Au solubility. Nevertheless, pressure has a strong, negative effect on sulfur solubility. Since gold dissolution is closely related to the behaviour of sulfur in reducing and moderately oxidizing conditions, pressure has therefore a significant but indirect effect on Au solubility. The present study confirms that $\mathrm{Au}$ dissolution is mainly controlled by $f \mathrm{O}_{2}$ in $\mathrm{S}$-free melts and 2 
by a complex interplay of $f \mathrm{O}_{2}$ and melt $\mathrm{S}^{2-}$ concentration in sulfide-saturated melts, at given temperature. In addition, we propose that the transition from sulfide $\left(S^{2-}\right)$ to sulfate $\left(S^{6+}\right)$ species in melt is shifted towards more oxidizing conditions when pressure and the degree of melt polymerization increase. If this is true, this may have important consequences during mantle melting and magma ascent. In particular, if mantle melting occurred in moderately oxidizing conditions, a small degree of partial melting would allow the primary melts to become Au-enriched but the relatively high pressure would move the sulfide-sulfate transition to more oxidizing conditions, making the primary melts saturated with sulfide phases that would sequester gold from the melt. During magma ascent, the decreasing pressure would favour the destabilization of sulfides and the release of gold to the silicate melt. However, at shallow levels, decreasing pressure, magma evolution, and varying redox conditions would be continuously competing to concentrate or fractionate gold.

Keywords: Gold solubility, Pressure, $f \mathrm{O}_{2}$, Sulfur solubility, Sulfide-sulfate transition, Arc magmas, Piston-cylinder experiments, $\mathrm{Au}-\mathrm{Cu}-\mathrm{Mo}$ deposits. 


\section{INTRODUCTION}

$\mathrm{Au}-\mathrm{Cu}-\mathrm{Mo}$ deposits represent major metal resources known to be spatially and temporally associated with intrusive, subduction-linked calc-alkaline magmatism and, according to some studies, notably with particular arc magmas whose petrogenesis may involve garnet fractionation (i.e., adakitic melts), either by slab partial melting in the upper mantle or by deep crustal melting/fractionation (e.g., Jégo et al., 2005 and references therein; Zellmer et al., 2012; see also Richards and Kerrich, 2007 for a synthesis). Although the bulk of the ore metals seems to originate from the magmas, there is as yet no consensus on processes responsible for their concentration. However, the fact that primary ore minerals are predominantly sulfides (e.g., Kesler et al., 2002) has led to the suggestion that sulfur may play an important role in metal enrichment processes at the magmatic stage (Sillitoe, 1997).

Most of previous studies focusing on the behavior of gold in silicate melts aimed to determine the partitioning of gold between silicate liquid and sulfide phases (e.g., Bezmen et al., 1994; Fleet et al., 1996, 1999; Crocket et al., 1997; Jugo et al., 1999; Simon et al., 2007; 2008; Bell et al., 2009). Even though these experimental studies quantify the solubility of gold in the melt, the reported melt gold concentrations depend on the starting composition of the metal-doped sulfides. Nevertheless, Borisov and Palme (1996) report Au solubility values from $\sim 300$ to $2000 \mathrm{ppb}$ in anhydrous haplobasaltic S-free melt at 1 atm and $1300-1400^{\circ} \mathrm{C}$, and suggest that gold dissolution is dependent on the oxidation state by involving $\mathrm{Au}_{2} \mathrm{O}$ species. Jégo et al. (2010) report much lower solubility values (30-240 ppb Au) in S-free dacitic compositions at $4 \mathrm{kbar}$ and $1000^{\circ} \mathrm{C}$, but also show an increase of melt $\mathrm{Au}$ contents with $f \mathrm{O}_{2}$ in a way consistent with the dissolution of gold as both $\mathrm{Au}^{1+}$ and $\mathrm{Au}^{3+}$ species. In presence of 4 
sulfur, Simon et al. (2007) report gold solubility values up to $1100 \mathrm{ppb}$ in Cl-bearing haplogranitic melt at $\sim \mathrm{NNO}\left(800^{\circ} \mathrm{C}, 1-1.5 \mathrm{kbar}\right)$ and Jugo et al. (2005) give evidence for a solubility on the order of $\sim 500 \mathrm{ppb}$ in anhydrous basaltic melt $\left(1300^{\circ} \mathrm{C}, 10 \mathrm{kbar}\right)$ in reducing conditions, while a solubility value of $\sim 800 \mathrm{ppb}$ is reported by Bezmen et al. (1994) in the Bushveld Complex melt $\left(1300^{\circ} \mathrm{C}, 4 \mathrm{kbar}, \sim \mathrm{NNO}\right)$. Those three solubility values are noticeably lower than those obtained by Jégo and Pichavant (2012) in dacitic compositions $\left(1000^{\circ} \mathrm{C}, 4 \mathrm{kbar}\right)$, which range from 1200 to $4250 \mathrm{ppb}$ Au at $\sim \mathrm{NNO}-1$ and from 865 to 2400 $\mathrm{ppb}$ at $\sim \mathrm{NNO}+1.5$, depending mainly on the melt $\mathrm{S}$ content. Jugo et al. (1999) also report high gold solubility values, i.e., $\sim 4 \pm 2 \mathrm{ppm}$ in hydrous haplogranitic melt $\left(850^{\circ} \mathrm{C}, 1 \mathrm{kbar}\right)$ in moderately oxidizing conditions ( $\sim \mathrm{NNO} \pm 0.5)$. Recently, Botcharnikov et al. (2010) presented the first experimental Au solubility data in S-bearing hydrous intermediate (i.e., andesitic) silicate melts around NNO. Similarly to Jégo and Pichavant (2012), the data reported in Botcharnikov et al. (2010) suggest a positive correlation between the concentrations of Au and $\mathrm{S}$ dissolved in the melt under reducing/moderately oxidizing conditions. However, Botcharnikov et al. (2010) show significantly lower Au solubility values (from 300 to 2500 ppb) compared to Jégo and Pichavant (2012), and Zajacz et al. (2012; 2013) also report similarly lower Au concentrations (from 220-1550 ppb $\mathrm{Au}$ and from $~ 60-3200 \mathrm{ppb} \mathrm{Au}$, respectively) in reducing to moderately oxidizing conditions at $1000^{\circ} \mathrm{C}$ and $2 \mathrm{kbar}$. Nevertheless, another study by Botcharnikov et al. (2011) reports much higher gold concentrations (from 250 to $8000 \mathrm{ppb} \mathrm{Au}$ ) in basaltic to andesitic melts over an $f \mathrm{O}_{2}$ range going from NNO-1 to $\sim \mathrm{NNO}+2$, which emphasize the role of $f \mathrm{O}_{2}$ in controlling the incorporation of gold in melt. Under more oxidizing conditions $\left(f \mathrm{O}_{2} \geq \mathrm{NNO}+3\right)$, Jégo and Pichavant (2012) show that gold dissolution is much less effective - with solubility values around $600 \mathrm{ppb} \mathrm{Au}$ - and seems independent on the melt S content, yet very high. Thus, the 
respective effects of the oxidation state and the presence of sulfur on gold solubility are partly understood so far, contrarily to the influence of pressure and temperature.

Although no previous study has focused on its pressure dependence, the solubility of gold in silicate melts may vary with depth in a significant way, independently of any fractionation process. If this is true, it may lead to important implications for the gold budget of arc magmas rising up through the mantle wedge and the arc crust. A few other ore-forming metals $(\mathrm{Mo}, \mathrm{Pt}, \mathrm{Te}, \mathrm{Se}, \ldots)$ as well as sulfur have been previously studied to estimate the pressure effect on their solubility in silicate melts (e.g., Mavrogenes and O'Neill, 1999; Ertel et al., 2006; Rose-Weston et al., 2009; Burkemper and Agee, 2010), but all experiments were performed at much higher pressures, some of these studies aiming to constrain early Earth evolution and core-mantle differentiation. Here, we aim to evaluate the ability of the silicate melt to incorporate gold during partial melting of a deep source (upper mantle or lower crust), saturated with sulfide phases or not, and see how the initial gold budget of a primary melt will evolve during its adiabatic ascent through the arc crust. Such information is indeed decisive to understand if the pre-concentration of $\mathrm{Au}$ at the magmatic stage is pressure-dependent and, therefore, to determine to which extent magmas are able to participate in the formation of ore deposits.

We approach the problem by providing new experimental $\mathrm{Au}$ solubility data in representative arc magmas at 0.9 and $1.4 \mathrm{GPa}$, with and without sulfur, and comparing them to previously published data at lower pressure. Understanding the relative effects of critical parameters such as pressure, oxygen fugacity, and sulfur fugacity on the solubility of gold in intermediate silicate melts is the central question addressed in this study. The experimental results allow the transport properties for Au of S-free and S-bearing magmas to be compared 6 
at different depths. They also place constraints on mechanisms of $\mathrm{Au}$ complexation in hydrous magmatic liquids of dacitic composition, typical of arc settings.

\section{STARTING MATERIALS AND EXPERIMENTAL STRATEGY}

\subsection{Starting materials}

Our experiments were performed in parallel on two natural calc-alkaline samples from the North Luzon arc (Philippines). They are both dacitic in composition, one being representative of a typical adakite (Bal2) whereas the other one stands for an intermediate adakite (Pin Dac) according to the definition of Jégo et al. (2005) (a summary of this adakite classification is given in Jégo et al., 2010). Recent ( $<20 \mathrm{Ma})$ magmatism in the North Luzon arc is linked to the current subduction of the South China Sea plate along the Manila Trench, and includes a range of arc rocks (Sajona and Maury, 1998; Prouteau et al., 2000; Yumul et al., 2000; Bellon and Yumul, 2001; Jégo et al., 2005). World-class Cu-Au deposits are spatially and temporally associated with this recent magmatic activity, as shown by the chain of porphyry copper deposits extending from Dizon in the south to Lepanto in the north, and the epithermal Au deposits from the Baguio district (Bellon and Yumul, 2000; Imai, 2001; 2002). In the Baguio district, there is an intimate association between intrusive rocks and mineralization (Santo Tomas II Cu-Au porphyry and Antamok and Acupan epithermal $\mathrm{Au}$ deposits, Imai, 2001; 2002; Polvé et al., 2007). The selected starting rocks are samples of this recent magmatic episode in North Luzon. Their respective sampling location and geochemical characteristics (major and trace elements) are described in detail by Jégo et al. (2010). It is worth stressing that both starting samples have similar $\mathrm{SiO}_{2}, \mathrm{Al}_{2} \mathrm{O}_{3}$ and alkaline contents 
(Table 1), whereas Bal2 is slightly richer in $\mathrm{MgO}$ and $\mathrm{Na}_{2} \mathrm{O}$ and poorer in $\mathrm{FeO}_{\mathrm{T}}$, features characteristic of an adakitic imprint. In addition, although both samples show enriched Large Ion Lithophile elements (LILE) and Light Rare Earth Elements (LREE) and depleted High Field Strength Elements (HFSE) and Heavy Rare Earth Elements (HREE), the HREE and yttrium (Y) contents are significantly lower in Bal2 than in PinDac, consistent with a more extensive fractionation of these elements by garnet during adakite genesis (e.g., Defant and Drummond, 1990; Sen and Dunn, 1994), as evidenced by the very high Sr/Y ratio of Bal2 (197.8) compared with the relatively low one of PinDac (42.4).

Sulfur contents in starting materials (double-melting glass) are below the detection limits of the FE-EPMA apparatus (Table 1), i.e. less than $30 \mathrm{ppm}$. Besides the fact that we avoided starting samples containing anhydrite crystals, such low S contents are likely due to volatilization and loss of sulfur during the preparation by double melting of the starting rock glass powder at $1400^{\circ} \mathrm{C}$ in air. The bulk gold contents of our samples are quite low (12 and 38

ppb; Table 1), close to the detection limits (which are generally $\leq 10 \mathrm{ppb}$ ) of the analytical equipment (ICP-MS, Toulouse, France); these Au concentrations are in the same range as those measured by Borisova et al. (2006) in the rhyolitic matrix glass of the Pinatubo 1991 white dacite $(22 \pm 8 \mathrm{ppb})$. Note that the typical adakite Bal2 is the most Au-enriched.

\subsection{Experimental Strategy}

The aim of this study is to investigate the effect of pressure on the solubility of Au in S-free and S-bearing hydrous intermediate silicate melts at the magmatic stage (i.e., before exsolution of the magmatic volatile phase and partitioning of Au towards ore-forming 8 
hydrothermal fluids) in subduction zone settings, in order to qualitatively and quantitatively evaluate the evolution of melt transport properties for gold in both adakitic and non-adakitic magmas from their respective source region (upper mantle wedge or deep arc crust) to levels of emplacement (upper crust). To simulate conditions of evolution of intermediate arc melts as closely as possible in the experiments, pressures of 0.9 and $1.4 \mathrm{GPa}$ were chosen to account for lower arc crust $(\sim 30 \mathrm{~km}$ depth) and upper mantle wedge $(\sim 50 \mathrm{~km} \mathrm{depth})$ magmatic conditions. An elevated temperature $\left(975-1000^{\circ} \mathrm{C}\right)$, close to or above the liquidus of dacitic compositions such as the two starting rocks (e.g., Prouteau and Scaillet, 2003), was adopted. Hydrous conditions were imposed, the liquidus temperature allowing the concentration of $\mathrm{H}_{2} \mathrm{O}$ in melt to be varied without inducing significant crystallization of silicate phases. The experimental $\mathrm{fO}_{2}$ could not be controlled or trivially varied since hydrogen fugacity is intrinsic of the piston-cylinder assembly (due to the solid state of the pressure-media) which imposes redox conditions around $\sim \mathrm{NNO}$; however, $f \mathrm{O}_{2}$ was estimated by the solid sensor technique for more accuracy. Also, in order to explore the effect of sulfide saturation on $\mathrm{Au}$ solubility at high pressure, half of the experiments reported in this study were performed with addition of elemental S.

\section{EXPERIMENTAL AND ANALYTICAL METHODS}

\subsection{Experimental Charges}

Each of the two natural samples was ground in an agate mortar, then placed in a $\mathrm{Pt}$ crucible and fused at $1400^{\circ} \mathrm{C}, 1 \mathrm{bar}$, in air for 4 hours. Two cycles of melting were performed to produce chemically homogeneous glasses which were then crushed. For each run, about 20 
$\mathrm{mg}$ of this starting glass powder were loaded in two pure Au capsules $(1.8 \mathrm{~mm} \mathrm{ID,} 2.0 \mathrm{~mm}$ OD, $\sim 8 \mathrm{~mm}$ length). For half the sample charges, elemental sulfur was added in order to reach sulfide saturation and homogeneously mixed with the glass powder before capsule loading: $\sim 1 \mathrm{wt} \% \mathrm{~S}$ added in 3 runs $(10,11$ and 15$), \sim 15 \mathrm{wt} \% \mathrm{~S}$ added in run 16, and $\sim 7.5 \mathrm{wt} \% \mathrm{~S}$ added in run 17. In all sample charges, variable amounts of deionized distilled water ( $10-15 \mathrm{wt} \%$ of the total charge) were added to the glass powder $( \pm S)$, depending on the desired melt water content ( $c f$. Table S1). In S-free runs, the charges are not vapor-saturated (since melt $\mathrm{aH}_{2} \mathrm{O}$ is less than unity; $c f$. Table 2), but in S-bearing runs all charges are vapor-saturated even if $\mathrm{aH}_{2} \mathrm{O}$ $<1$ (owing to the formation of a fluid phase induced by the sole presence of sulfur in the system; cf. Jégo and Pichavant, 2012). In every experiment, one additional Au capsule containing the $f \mathrm{O}_{2}$ sensors (see below) was placed together with the two sample capsules in the sample cell of the apparatus. The three Au capsules were closed with a single gold lid topped by a nickel lid, capsule sealing being ensured by pressure welding during experiment (Nakamura and Watson, 2001).

In this study, the source of $\mathrm{Au}$ was the container capsule. Au is relatively inert with respect to Fe-bearing charges. It is known experimentally to be quite permeable to $\mathrm{H}_{2}$ at elevated temperatures (e.g., Chou, 1986; Gunter et al., 1987; Linnen et al., 1995; Truckenbrodt and Johannes, 1999). For our experimental conditions (in particular, temperature and Au capsule thickness), and depending on the amount of elemental sulfur loaded into the capsule that will either have to be reduced or oxidized, charges equilibrate with the $f \mathrm{H}_{2}$ imposed by the piston cylinder assembly in timescales of several dozen minutes (Scaillet et al., 1992; Schmidt et al., 1997). This is much less than our experimental durations ( $100 \mathrm{~h}$ ), supporting that redox control is effectively achieved in our experiments (Jégo et al., 10 
2010).

3.2. $\mathrm{fO}_{2}$ Sensors

Experimental redox conditions were accurately determined by the $\mathrm{CoO}+\mathrm{Co}-\mathrm{Pd}$ solid sensor technique (Taylor et al., 1992). Although this redox sensor was designed and tested for pressures and temperatures lower than our experimental conditions, the fact that all calculated $f \mathrm{O}_{2}$ values are very close to the NNO buffer (between NNO-0.6 and NNO+0.2; $c f$. Table 2) whereas the intrinsic redox conditions imposed by the piston cylinder assembly are known to be around NNO - shows the accuracy of such redox sensors at high $\mathrm{P}$ and $\mathrm{T}$ and gives an $a$ posteriori validation of their use in our experiments.

The sensor assemblage consisted of a mixture of $\mathrm{Co}+\mathrm{Pd}$ metal powders in variable proportions, plus metal oxide (CoO). For each experiment, two pellets of the sensor assemblage were prepared, with respectively a high and low $\mathrm{Co} / \mathrm{Pd}$ ratio. These were loaded in a $\sim 8 \mathrm{~mm}$ length Au capsule containing $\sim 10 \mathrm{mg}$ of deionized water, lined with $\mathrm{ZrO}_{2}$ powder ( $\sim 0.5 \mathrm{~mm}$ thick) to prevent significant alloying between the pellets and the capsule walls (in most cases, less than 2.5 at.\% Au were measured in run product Co-Pd alloys). The sensor $\mathrm{Au}$ capsule was placed together with the experimental Au capsules inside the sample cell.

\subsection{Experimental Equipment and Procedure}

Experiments were performed using an end-loaded "Rockland Research" piston cylinder (PC) apparatus at the Department of Earth Science, Tohoku University (Japan). Experiments were conducted at 0.9 and $1.4 \mathrm{GPa}$ with run temperatures varying between 975 
and $1000^{\circ} \mathrm{C}$, and stopped by shutting the power off, which allowed the melt to be quenched relatively rapidly $\left(\mathrm{T}<100^{\circ} \mathrm{C}\right.$ after 1 minute). All experiments used 3/4-inch pyrex-NaCl assemblies with straight graphite heaters and $\mathrm{Al}_{2} \mathrm{O}_{3}$ spacers above and below the capsules. For each run, three Au capsules ( 2 samples +1 sensor) were tightly placed inside three holes drilled in a single outer capsule made of machinable ceramics $\left(\mathrm{MgO}+\mathrm{Al}_{2} \mathrm{O}_{3}+\mathrm{F}\right.$-micas; 10 mm OD, 8 mm length; Macor ${ }^{\mathrm{TM}}$ of Ishihara chemical Co. Ltd.), except for runs 1 and 2 which were performed by using outer capsules made of pure $\mathrm{Ni}$ (according to the routine protocol at the host laboratory). Care was taken to position the capsules within the hotspot of the assembly and within $1 \mathrm{~mm}$ of the thermocouple tip. For this assembly, temperature gradients across the sample are expected to be less than $20^{\circ} \mathrm{C}$ based on calibration experiments using different run temperatures and several sample cell configurations. Temperature was controlled using "W/Re 5-26" thermocouples (W95Re5/W74Re26) and a "Eurotherm" temperature controller and is precise to within $3^{\circ} \mathrm{C}$. Pressure is converted from load, the actual sample pressure being within $95 \%$ of the load pressure in our experiments. Recovered capsules were mounted in epoxy, cut in half, polished successively to a final diamond grit of $1 \mu \mathrm{m}$, and coated with a $\sim 0.03 \mu \mathrm{m}$ carbon film by using a standard thermal evaporation technique.

3.4. Analytical Methods

\subsubsection{Major and Minor Elements}


with a JEOL $J X A-8500 F$ electron microprobe (IES-Academia Sinica facility, Taipei, Taiwan) equipped with 5 spectrometers. All data (except for sulfur) were obtained using $12 \mathrm{kV}$ acceleration voltage, $3 \mathrm{nA}$ beam current, a defocused electron beam ( $10 \mu \mathrm{m}$ diameter), and peak and baselines counting time of $10 \mathrm{~s}$ and $5 \mathrm{~s}$, respectively. Numerous analyses $(\sim 50-100)$ were performed on each sample to increase analytical accuracy and check for the chemical homogeneity of the glasses. Natural and synthesized reference minerals were used as standards: forsterite (Tohoku Univ.) for $\mathrm{Si}$ and $\mathrm{Mg}$, corundum (JEOL Ltd.) for $\mathrm{Al}$ and $\mathrm{Ca}$, rutile (JEOL Ltd.) for Ti, fayalite (Tohoku Univ.) for Fe, tephroite (Tohoku Univ.) for Mn, jadeite (JEOL Ltd.) for Na, adularia for K, and F-apatite (Astimex Standards Ltd.) for P.

When present in the S-bearing charges, the sulfur-bearing mineral phases at equilibrium were always sulfides (i.e., no sulfate), so the proportion of sulfur occurring as $\mathrm{S}^{6+}$ species in glass was assumed to be very minor, not more than a few percent considering the $f \mathrm{O}_{2}$ of our experiments ( $c f$. Jugo et al., 2010). In addition, we used the $\mathrm{SK} \alpha$ peak shift method on the electron microprobe (Klimm et al., 2012) to confirm the oxidation state of sulfur in some experimental glasses from Jégo and Pichavant (2012). The results (Fig. S1) suggest that sulfur is mostly expressed as $\mathrm{S}^{2-}$ in the run products of the present study since their $f \mathrm{O}_{2}$ estimates all range between those of charges $\mathrm{C} 4 \mathrm{E}$ and $\mathrm{C} 1 \mathrm{C}$ whose $\mathrm{SK} \alpha$ peaks are aligned with that of pyrrhotite. Therefore, only the position corresponding to $\mathrm{S}^{2-}$ was chosen for all $\mathrm{S}$ bearing charges, and pyrite was used for calibration. Sulfur in the starting glasses was measured by using the same FE-EPMA facility. Sulfur contents were always found to be below the detection limit (Table 1), even when using $15 \mathrm{kV}$ acceleration voltage, $50 \mathrm{nA}$ beam current, a defocused electron beam $(10 \mu \mathrm{m}$ diameter $)$ and peak counting times as long as 500 s. Such analytical parameters lower the limit of detection to less than $30 \mathrm{ppm} \mathrm{S}$ (calculated as three times the standard deviation of replicate measurements). 
The composition of silicate mineral phases (mostly clinopyroxene and amphibole) was determined as above. The major element composition of oxide (magnetite) and sulfide (pyrrhotite) mineral phases was determined using $15 \mathrm{kV}$ acceleration voltage, $10 \mathrm{nA}$ beam current, a focused electron beam $(\sim 3 \mu \mathrm{m}$ diameter). Hematite, pyrrhotite, anhydrite and pure metals were used as standards.

The JEOL JXA-8500F electron microprobe was also used for determining the composition of the solid $\mathrm{fO}_{2}$ sensors. The metals analyzed were $\mathrm{Co}, \mathrm{Pd}, \mathrm{O}, \mathrm{Ni}$ and $\mathrm{Au}$ to control the absence of any contamination from the capsule. The data were obtained using a counting time of $20 \mathrm{~s}$, an acceleration voltage of $20 \mathrm{kV}$, a beam current of $20 \mathrm{nA}$ and a focused electron beam ( $1 \mu \mathrm{m}$ diameter). Pyrrhotite and pure metals were used for calibration.

\subsection{2. $\mathrm{H}_{2} \mathrm{O}$ Concentrations in Experimental Glasses}

Glass $\mathrm{H}_{2} \mathrm{O}$ contents were estimated by difference to $100 \mathrm{wt} \%$ (i.e., total of oxides) from the EPMA analyses of major and minor elements in glasses after correction for the loss of alkalis $(\mathrm{Na}, \mathrm{K})$ under the electron beam. To minimize the effect of migration of the alkalis in these hydrated glasses, their measured concentrations were adjusted by applying correction factors determined from the analysis of the alkalis in the anhydrous starting glasses, taken as secondary reference. Peak counting times and analytical conditions were kept the same for all charges (including starting materials), so the correction factors were calculated as a function of the estimated glass $\mathrm{H}_{2} \mathrm{O}$ content for a given melt composition. The numerous EPMA analyses performed on each glass lead to a good statistical estimation of the melt $\mathrm{H}_{2} \mathrm{O}$ concentrations and show that water is homogeneously distributed within the silicate charges. 


\subsubsection{Gold concentrations in Experimental Glasses}

Gold contents in experimental glasses were determined using the laser ablation ICPMS facility at IFREE (JAMSTEC, Japan). This system consisted of an inhouse $193 \mathrm{~nm}$ ArF excimer laser using COMPex 102 (Coherent) laser source coupled to a Thermo Fischer Scientific, VG PQ3 quadrupole ICP-MS. NIST 612 was used as the external standard for Au and the isotope 29 of $\mathrm{Si}\left({ }^{29} \mathrm{Si}\right)$ was used as an internal standard. The ICP-MS was tuned to obtain maximum sensitivity and stability using mid mass ${ }^{115} \mathrm{In}$ peak and to obtain low oxide yield using ThO/Th to be less than $0.3 \%$.

A time-resolved analysis (TRA) was used, constituted of a first part corresponding to the gas blank (laser off), followed by a second part corresponding to the sample signals (laser on). The ablation was performed by drilling; thus the hole drilled becomes progressively deeper with time. The data were obtained using $180 \mathrm{~mJ}$ energy at laser source and a fluence of $5 \mathrm{~J} / \mathrm{cm}^{2}$ on sample surface. The diameter of the laser beam and the repetition rate were optimized to $20 \mu \mathrm{m}$ and $5 \mathrm{~Hz}$, respectively, resulting in a 20-25 $\mu \mathrm{m}$ depth hole after $40 \mathrm{~s}$ ablation. A background (gas blank) time of $20 \mathrm{sec}$ was chosen (sweep time of $\sim 163 \mathrm{msec}$ and dwell time of $20.48 \mathrm{msec}$ per peak). At least 10 analyses were made for each experimental charge to check for homogeneity. NIST 612 standard $(\mathrm{Au}=4.58 \mathrm{ppm}$; Sun et al., 2004; Jenner et al., 2010) was used for calibration and the calculation of $\mathrm{Au}$ concentrations. The washout time of the ablation cell was $20 \mathrm{sec}$ (i.e., slow), and a signal-smoothing device was used, so that all the signals were averaged out. Only flat signal regions, or regions with inherent and limited variability in the LA-ICPMS signal (likely due to the presence of finely dispersed, tiny, nanometer-size (or less) quench gold nuggets, invisible in SEM images) from the glass matrix in the TRA were chosen for $\mathrm{Au}$ abundance calculations after gas blank 
subtraction. No large (micron-size) gold nuggets were observed in SEM images nor detected from laser ablation signals. Large negative-positive spiky signals from both silicate crystals and sulfide inclusions or micro-crystals were neglected. The ${ }^{181}$ Ta peak was also analyzed in order to monitor ${ }^{197} \mathrm{TaO}^{+}$interference on ${ }^{197} \mathrm{Au}$, which was negligible during analyses.

Gold was found to be homogeneously distributed in all glasses, as shown by the low ratios of standard deviation over melt gold concentration $\left(\sigma /[\mathrm{Au}]_{\text {melt }}\right)$ of the LA-ICPMS analyses of Au concentration in glass (average $\sigma /[\mathrm{Au}]_{\mathrm{melt}}=0.14 ; \mathrm{min} .=0.01 ;$ max. $=0.28$ ). The highest ratios are found in the charges of the first two runs, performed with nickel outer capsule, and in the Au-richest charge; they remain well below 30\%, though, which is satisfactory given the very low gold concentrations in the sulfur-free glasses (around $150 \mathrm{ppb}$; Table 2).

\subsubsection{Analytical Data Processing}

For each charge, water activity $\left(\mathrm{aH}_{2} \mathrm{O}\right)$ was calculated from the $\mathrm{H}_{2} \mathrm{O}$ content and the major element (excluding S) composition of glass, using the model of Burnham (1979). Oxygen fugacity $\left(f \mathrm{O}_{2}\right)$ inside the experimental charges was calculated from both experimental $f \mathrm{H}_{2}$ and $f \mathrm{H}_{2} \mathrm{O}$ (the latter obtained from $\mathrm{aH}_{2} \mathrm{O}$ ), following the water dissociation equilibrium:

$$
f \mathrm{O}_{2}=\left(K_{W} \cdot f \mathrm{H}_{2} \mathrm{O} / f \mathrm{H}_{2}\right)^{2}
$$

with $K_{\mathrm{w}}$ (taken from Robie et al., 1978) being expressed as:

$\log K_{W}=49.694-7.967 \cdot 10^{-2} \cdot T+53.364 \cdot 10^{-6} \cdot T^{2}-13.333 \cdot 10^{-9} \cdot T^{3} \quad(T$ in $\mathrm{K})$

Experimental $f \mathrm{H}_{2}$ was determined from the sensor capsule since $f \mathrm{O}_{2}$ inside the sensor capsule is known from the composition of the Co-Pd alloy phase (Taylor et al., 1992) and $\mathrm{H}_{2} \mathrm{O}$ is 
present in excess inside the sensor capsule (hence $f \mathrm{H}_{2} \mathrm{O}=f \mathrm{H}_{2} \mathrm{O}^{\circ}$ ). The $f \mathrm{O}_{2}$ is known to better than $0.25 \log$ units (Scaillet et al., 1995; Martel et al., 1999). Throughout this study, the $f \mathrm{O}_{2}$ is expressed relative to the $\mathrm{NNO}(\mathrm{Ni}-\mathrm{NiO})$ oxygen buffer whose value was calculated by using the calibration of Pownceby and O'Neill (1994) as a function of P and T.

The fugacity of sulfur $\left(f \mathrm{~S}_{2}\right)$ was calculated from the expression of Liu et al. (2007) which considers $\mathrm{T}, \mathrm{fO}_{2}$, and the mole fraction of $\mathrm{FeO}$ in melt, and includes a correction term for pressure:

$\log f S_{2}^{P, T}=6.7-\frac{12800}{T}-2 \cdot \log X_{F e O}+\Delta F M Q+\Delta V_{r} .(P-1) / 2.303 . R T$

where $\mathrm{T}$ is in $\mathrm{K}, \mathrm{P}$ in bar, $\Delta \mathrm{V}_{\mathrm{r}}=0.904 \mathrm{~J} / \mathrm{bar}$, and $\Delta \mathrm{FMQ}$ refers to the $f \mathrm{O}_{2}$ expressed relative to the FMQ (fayalite-magnetite-quartz) oxygen buffer. According to Liu et al. (2007), their equation reliably estimates $f \mathrm{~S}_{2}$ to within an uncertainty of $0.7 \log$ units.

$f \mathrm{SO}_{2}$ and $f \mathrm{H}_{2} \mathrm{~S}$ were calculated from $\mathrm{T}$ (in $\mathrm{K}$ ), $f \mathrm{~S}_{2}, f \mathrm{O}_{2}$ and $f \mathrm{H}_{2} \mathrm{O}$ by using the equilibrium constants of Ohmoto and Kerrick (1977), according to the relations:

$f \mathrm{SO}_{2}=K_{\mathrm{SO}_{2}} \cdot f \mathrm{O}_{2} \cdot\left(f \mathrm{~S}_{2}{ }^{1 / 2}\right) \quad$ with $\log K_{\mathrm{SO}_{2}}=(18929 / \mathrm{T})-3.783$

$f \mathrm{H}_{2} \mathrm{~S}=\mathrm{K}_{\mathrm{H}_{2} \mathrm{~S}} \cdot f \mathrm{H}_{2} \mathrm{O} \cdot\left(f \mathrm{~S}_{2}{ }^{1 / 2}\right) /\left(f \mathrm{O}_{2}{ }^{1 / 2}\right)$

with $\log K_{H_{2} S}=(-8117 / T)+(0.188 \cdot \log T)-0.352$

\section{RESULTS}

Results for a total of 27 experimental charges are reported, including 11 S-added charges. Experimental conditions and results are summarized in Table 2.

4.1. Experimental Parameters $\left(\mathrm{aH}_{2} \mathrm{O}, f \mathrm{O}_{2}, f \mathrm{~S}_{2}\right)$ 
$\mathrm{H}_{2} \mathrm{O}$ contents in glass range from 5.4 to $14.8 \mathrm{wt} \%$ (Table 2), with corresponding $\mathrm{aH}_{2} \mathrm{O}$ values ranging from 0.41 to 'sub-saturation' $\left(\mathrm{aH}_{2} \mathrm{O}=0.96\right)$. Bal2 melt $\mathrm{H}_{2} \mathrm{O}$ concentration at sub-saturation is greater than $12 \mathrm{wt} \%$ at $0.9 \mathrm{GPa}$ (as shown by charge Au16-2) and $15 \mathrm{wt} \%$ at 1.4 GPa (charge Au17-1). It differs little between the two investigated compositions (for PinDac, $\mathrm{aH}_{2} \mathrm{O}=0.90$ with $11.3 \mathrm{wt} \% \mathrm{H}_{2} \mathrm{O}$, at $0.9 \mathrm{GPa}$; charge Au13-1), in agreement with their similar major element compositions.

Oxygen fugacity values range from NNO-0.63 to NNO+0.21 (Table 2). A narrow $f_{2}$ range has thus been investigated, centered around the NNO buffer which is thought to correspond closely to the intrinsic $\mathrm{fO}_{2}$ imposed by the piston cylinder assembly. In S-bearing charges, the calculated sulfur fugacity values vary little in most experiments $\left(0.55<\log f \mathrm{~S}_{2}<\right.$ 0.96), except for the run $17(1.4 \mathrm{GPa}, 7.5 \mathrm{wt} \% \mathrm{~S}$ added $)$ which shows very high $\log f \mathrm{~S}_{2}$ values (3.55 and 3.84). In a similar way, $f \mathrm{SO}_{2}$ and $f \mathrm{H}_{2} \mathrm{~S}$ range from 0.76 to 2.73 , and from 3.36 to 5.46, respectively (Table 2). It is worth noting, though, that these $f \mathrm{H}_{2} \mathrm{~S}$ estimates appear quite high, likely because the equilibrium constant $K_{\mathrm{H} 2 \mathrm{~S}}$ of Ohmoto and Kerrick (1977) and the water dissociation constant $K_{\mathrm{W}}$ of Robie et al. (1978) may not be totally valid at the experimental pressures of the present study. Those values should therefore be treated cautiously.

4.2. Experimental Products and Compositions

All experimental charges comprise silicate melt quenched to glass and a small proportion (<10 wt \% total) of crystalline phases (silicates, sulfides, oxides, Table 2; see Fig. 18 
1 for textures typical of most of our run products). It is worth noting that, for some $\mathrm{H}_{2} \mathrm{O}$-rich charges, the silicate melt could not be completely quenched to a glass at such high pressures but represented a kind of gel substance corresponding to a supercritical phase, as observed in previous studies (e.g., Bureau and Keppler, 1999). In sulfur-free charges, a vapour phase is considered to be present (i.e., the system at equilibrium is fluid-saturated) when bubbles can be observed in EDS images of the charges ( $c f$. Table 2). In S-bearing charges, a vapour phase is considered to be systematically present even if the melt is strictly-speaking $\mathrm{H}_{2} \mathrm{O}$ undersaturated $\left(\mathrm{aH}_{2} \mathrm{O}<1\right)$ under the experimental conditions: this is due to the relatively low solubility of S in silicate melts that systematically induces - besides the formation of a S-rich mineral phase at sulfide saturation (i.e., pyrrhotite) - the formation of a S-rich vapour phase (containing mainly $\mathrm{H}_{2} \mathrm{~S}+\mathrm{SO}_{2}+\mathrm{S}_{2}+\mathrm{H}_{2} \mathrm{O}$ ) at equilibrium, whatever the $\mathrm{aH}_{2} \mathrm{O}$ value calculated in the corresponding S-free system (see section 3.4.4). Then, the presence of a vapour phase may lead to significant partitioning of gold from liquid to vapour (e.g., Ulrich et al., 1999; Sun et al., 2004; Simon et al., 2007; Zajacz et al. 2010; 2012). Given the amount of $\mathrm{H}_{2} \mathrm{O}$ initially loaded in the capsules, the calculated melt $\mathrm{H}_{2} \mathrm{O}$ contents, and the approximate mass of the silicate charges, this vapour phase is present in very low amounts (probably less than a couple wt $\%$ of the total charge). In most charges, the exsolved fluid phase is external to the glass bead, i.e. it is not trapped as bubbles. Therefore, gold concentrations obtained by ablating the glass are believed to truly reflect those in the melt, and not the combined melt + fluid gold contents. In the few bubble-bearing charges, bubbles were large enough (from a few $\mu \mathrm{m}$ to a few dozen $\mu \mathrm{m}$ ) to allow us to clearly distinguish their own gold signal during laser ablation; thus all signals from bubbles were easily expelled before calculation of melt gold concentrations. We did not examine here the partitioning of gold between melt and fluid because the experimental setup of the present study was not designed to permit the 
determination of the fluid composition. Nevertheless, gold partitioning between fluid and melt has been investigated in a number of previous studies (Frank et al., 2002; Simon et al., 2003; 2005; 2007; Zajacz et al. 2010; 2012).

Major element compositions of experimental glasses are given in Table S2. When recalculated to anhydrous melt compositions, they variably differ from their respective starting glass composition according to the proportion of condensed phases, even if this one is generally low in the run products (i.e., $<10 \mathrm{wt} \%$ ). However, significant depletions in $\mathrm{FeO}$ and $\mathrm{MgO}$, and to a lesser extent in $\mathrm{TiO}_{2}$ and $\mathrm{Na}_{2} \mathrm{O}$, associated with slight enrichments in $\mathrm{Al}_{2} \mathrm{O}_{3}$ and $\mathrm{K}_{2} \mathrm{O}$, occur in most glasses when compared to the respective starting compositions (see Table 1). Given the generally low affinity of Fe for the Au capsule walls (although the extent of the loss of iron from the sample may be significant in some cases; $c f$. Ratajeski and Sisson, 1999), these chemical changes are realistically consistent with significant fractionation of pyrrhotite (or oxides in S-free charges) plus amphibole/clinopyroxene.

Diopside-rich clinopyroxenes (cpx; Table S3) and/or hornblende-rich amphiboles (amph; Table S4), from a few microns to more than $200 \mu \mathrm{m}$ in size (Fig. 1), appear as the silicate liquidus phases in almost all experiments (Table 2). Only two charges from this study are crystal-free (Au13-1 and -2), likely because these $\mathrm{H}_{2} \mathrm{O}$-rich charges are the two most oxidized of the S-free dataset; they are also the two most Fe-rich charges, which is consistent with the absence of Fe-bearing crystalline phases. All charges from runs 1 and 2 show large crystals of highly Ni-enriched olivine (> $30 \mathrm{wt} \%$ NiO; Table S4) generally located on the rim of the charges, near or in contact with the gold walls, some of the crystals exceeding $200 \mu \mathrm{m}$ in length. It is worth reminding that both runs 1 and 2 were conducted by using pure Ni outer capsules; the presence of sub-liquidus olivine phase in dacitic compositions and the 20 
occurrence of such high $\mathrm{Ni}$ contents in olivine crystals and silicate glass $(0.20-0.40 \mathrm{wt} \% \mathrm{NiO}$ vs. 0.02-0.07 wt\% $\mathrm{NiO}$ in all other charges; Table S2) suggest a strong diffusion of nickel through the gold capsule walls, as previously reported by Bell et al. (2009). This is the reason why the composition of the outer capsule was changed to an inert material (i.e., machinable ceramics) for the rest of the experiments. Oxides are found in three S-free runs (Au01,02 and 03); most have a size from $<1$ to a few $\mu \mathrm{m}$ (Fig. 1). A few satisfactory electron microprobe analyses were obtained for oxides from charges Au01-4 and 02-1 (Table S3); they show that these oxide phases are Ni-rich chromites in Au01-4 and Ni-rich Fe-oxides in Au02-1. Unfortunately, oxide crystals in Au03 charges were too small to be correctly analyzed; however, given the P-T- $f \mathrm{O}_{2}$ conditions of the present study, these oxides are most probably magnetite. Except for run 17, sulfides are present in every sulfur-added charge (Table 2; Fig. 1), ranging from $<1$ to more than $100 \mu \mathrm{m}$ in size. They all have similar $\mathrm{Fe} / \mathrm{S}$ atomic ratios, close to 1 , implying that these sulfides are pyrrhotites $\left(\mathrm{Fe}_{1-\mathrm{x}} \mathrm{S}\right.$, with $0<\mathrm{x}<0.2$; Table $\left.\mathrm{S} 5\right)$. No evidence was found (from the composition of sulfides) for the presence of an immiscible FeS-O sulfide liquid under our experimental conditions.

\subsection{Sulfur concentrations in S-bearing glasses}

Sulfur concentrations in experimental glasses (Table 2) range from 924 to $3364 \mathrm{ppm}$ at

$0.9 \mathrm{GPa}$ and from 261 to $3865 \mathrm{ppm}$ at $1.4 \mathrm{GPa}$, i.e. over more than one order of magnitude. When plotted as a function of $f_{2}$ (Fig. 2a), they entirely overlap and even largely exceed the glass sulfur contents measured in experimental charges with identical starting compositions at $0.4 \mathrm{GPa}$ (322 to $2422 \mathrm{ppm} \mathrm{S}$; Jégo and Pichavant, 2012), independently of the $\mathrm{fO}_{2}$ range. Most of the glass $\mathrm{S}$ contents presented here are also significantly higher than the sulfur 
concentrations experimentally determined in some previous gold solubility studies at lower pressures (0.12 GPa, Simon et al., 2007; 0.2 GPa, Botcharnikov et al., 2010) which do not exceed $400 \mathrm{ppm} \mathrm{S}$ in melt of comparable composition. However, the magnitude and the variability of the glass $\mathrm{S}$ concentrations of the present study are very comparable to those reported at 0.2 GPa in Botcharnikov et al. (2011), although their melt compositions are significantly more mafic (basaltic and andesitic) and their high sulfur concentrations were obtained at sulfate-dominated $\mathrm{fO}_{2}$ values. They show a wide range of melt $\mathrm{S}$ contents (from 530 to $6020 \mathrm{ppm}$ ) that increase with increasing $\mathrm{fO}_{2}$ (from NNO-0.6 to NNO+2.2). Here, the investigated $f \mathrm{O}_{2}$ range is much narrower, but the melt $\mathrm{S}$ concentrations also show a steep increase with increasing $f_{2}$, as previously described by Jugo (2009). Furthermore, the increase of melt $\mathrm{S}$ solubility with $\mathrm{fO}_{2}$ seems to be steeper with increasing pressure. Nevertheless, this last observation might represent an artefact since the two Bal2 charges at $1.4 \mathrm{GPa}$ (run 17) show abnormally high $f \mathrm{~S}_{2}$ values (3.55-3.84) due to the combination of higher pressure and higher initial $S$ content, while the rest of the S-bearing charges have relatively low and homogeneous $f \mathrm{~S}_{2}$ values comprised between 0.55 and 0.96 , close to those of the moderately oxidized charges at $0.4 \mathrm{GPa}$ (Fig. 2b). Besides, it appears that sulfur is mostly expressed in its reduced form (i.e., $\mathrm{S}^{2-}$ ) in our run products, and that sulfur dissolution is a function of the degree of melt polymerization and alkalinity (see detailed discussion in Supplementary Information).

\subsection{Gold solubility}

\subsubsection{Gold concentrations in sulfur-free glasses}


Gold concentrations in sulfur-free experimental glasses (Table 2) range from 82 to 225 $\mathrm{ppb}$ at $0.9 \mathrm{GPa}$, and the two charges at $1.4 \mathrm{GPa}$ contain respectively 68 and $142 \mathrm{ppb} \mathrm{Au}$ in melt. In Fig. 3a, melt Au contents are plotted versus oxygen fugacity and compared with data from previous studies at 0.4 GPa (Jégo et al., 2010), 0.2 GPa (Botcharnikov et al. 2011), and ambient pressure/high temperature (Borisov and Palme, 1996). All new data plot as a cluster at $f \mathrm{O}_{2} \sim \mathrm{NNO}$, showing no particular variation with $f \mathrm{O}_{2}$. Melt Au concentrations at $1.4 \mathrm{GPa}$ are not distinguishable from those at $0.9 \mathrm{GPa}$, nor from those at $0.4 \mathrm{GPa}$ with similar starting compositions. Although describing a parabolic trend with increasing $f \mathrm{O}_{2}$, as also proposed by Jégo et al. (2010) for $0.4 \mathrm{GPa}$ data, the melt $\mathrm{Au}$ contents at $0.2 \mathrm{GPa}$ all are higher than the data obtained at higher pressures along an identical $\mathrm{fO}_{2}$ range. Borisov and Palme (1996) report melt Au solubility values in reducing conditions (NNO-5 $<f \mathrm{O}_{2}<\mathrm{NNO}$ ) and particular P-T conditions $\left(1 \mathrm{~atm} / 1300-1400^{\circ} \mathrm{C}\right)$. These data also describe parabolic trends along their $\mathrm{fO}_{2}$ range and show higher melt gold concentrations than those measured at pressures $>0.4$ GPa. Therefore, the observations made from Fig. 3a suggest that there is no pressure effect, neither positive nor negative, on the solubility of gold in sulfur-free silicate melts at given $\mathrm{fO}_{2}$. This hypothesis seems to be also supported by the absence of any dependence of melt $\mathrm{Au}$ contents on pressure in Fig. 3b. Melt composition appears to have limited influence on gold solubility as well, whereas $\mathrm{fO}_{2}$ and temperature are the key parameters (see detailed discussion in Supplementary Information).

\subsubsection{Gold concentrations in S-bearing glasses}

The effect of sulfur on melt gold solubility is drastic at all pressures as gold 
concentrations in sulfur-bearing experimental glasses (Table 2) range from 813 to $6583 \mathrm{ppb}$ at $0.9 \mathrm{GPa}$, and the four charges at $1.4 \mathrm{GPa}$ range from $363 \mathrm{ppb}$ to almost $48 \mathrm{ppm} \mathrm{Au}$ in the melt. In Fig. 4a, Au contents are plotted versus the oxygen fugacity and compared with previously published data at 0.4 GPa (Jégo and Pichavant, 2012), 0.2 GPa (Botcharnikov et al., 2010; 2011) and $0.12 \mathrm{GPa}$ (Simon et al., 2007). The new data span a wide range of melt gold concentrations that overlap almost all other data at lower pressures, and describe a very steep positive correlation with $f \mathrm{O}_{2}$, similar to the $0.4 \mathrm{GPa}$ data at $\sim \mathrm{NNO}-1$ and NNO+1.5. In addition, this observed correlation seems at first sight in good agreement with the data of Botcharnikov et al. (2011) for S-bearing andesitic and basaltic compositions. The data obtained in the present study at $\mathrm{OO}_{2}$ close to $\mathrm{NNO}$ lie exactly on the steep trend of increasing $\mathrm{Au}$ concentration with $\mathrm{fO}_{2}$ just before the sulfide-sulfate transition. This observation suggests that a small increase in $\mathrm{fO}_{2}$ may cause a dramatic increase in $\mathrm{Au}$ content and could explain the differences between datasets obtained at different pressures. Nevertheless, the two most Auenriched charges, showing abnormally high gold contents (18 and $48 \mathrm{ppm}$ ) that can be explained by a combination of high pressure, high $f S_{2}$ (Fig. $4 b$ ), and high melt $\mathrm{S}$ contents, emphasize the role of sulfur - not only $\mathrm{fO}_{2}$ - and the importance of considering the interplay between different parameters in the mechanism of gold dissolution in silicate melts, as discussed in detail by Botcharnikov et al. (2011).

In Fig. 5a, Au contents are plotted versus the melt sulfur concentrations. At $0.9 \mathrm{GPa}$, $\mathrm{Au}$ contents are quite scattered but they globally increase with $\mathrm{S}$ and, importantly, they are not distinguishable from gold concentrations obtained at $0.2 \mathrm{GPa}$ by Botcharnikov et al. (2011). At 1.4 GPa, Au solubility displays nicely defined correlations with sulfur contents by describing an exponential increase. Interestingly, two out of these four charges plot along the 24 
$\mathrm{Au}-\mathrm{S}$ trend very well defined by the reduced/moderately oxidized data at $0.4 \mathrm{GPa}$. These results suggest, at all pressures and in reducing to moderately oxidizing conditions, a mechanism of gold dissolution based on an effective complexation between $\mathrm{Au}$ and $\mathrm{S}^{2-}$ in melt. In addition, the efficiency of this complexation does not seem to be related in any way to the effect of pressure since, at given melt $\mathrm{S}$ content, the solubility of gold is similar at 0.12 and 1.4 GPa. Apart from $f \mathrm{O}_{2}$ and melt $\mathrm{S}$ concentrations, other variables appear to have little influence on Au dissolution (see detailed discussion in Supplementary Information).

\section{DISCUSSION}

\subsection{Attainment of equilibrium}

Electron microprobe analyses of experimental glasses and mineral phases have standard deviations that are in most cases lower than analytical uncertainties (Tables S1-S4), indicating that these phases are homogeneous in terms of their major and minor elements (including sulfur). All charges also show homogeneous gold concentrations, with an average $\sigma /[\mathrm{Au}]_{\text {melt }}$ of only $14 \%$. The ability of the melt to homogenize with respect to Au can be tested by considering the amount of time required for $\mathrm{Au}$ to diffuse through the melt at run conditions. Calculation of the diffusion distance of gold can be performed by assuming that the diffusivity of $\mathrm{Au}\left(\right.$ taken as $\mathrm{Au}^{1+}$ ) is intermediate between that of the univalent metals $\mathrm{Na}$ and $\mathrm{Cs}$ (Simon et al., 2007). Thus, at $1000^{\circ} \mathrm{C}$ and for $6 \mathrm{wt} \% \mathrm{H}_{2} \mathrm{O}$ in the melt, a gold diffusivity of $\sim 10^{-10} \mathrm{~m}^{2} / \mathrm{s}$ is obtained from Watson (1994). This yields a diffusion distance of $6 \mathrm{~mm}$ for experimental durations of $100 \mathrm{~h}$. Therefore, our experimental conditions (durations, temperature and melt $\mathrm{H}_{2} \mathrm{O}$ contents) and capsule geometries (see above) effectively enabled 
gold to be homogeneously distributed within the melts, even though a significant proportion of $\mathrm{Au}^{3+}$ might have to be considered in the calculation for oxidizing experiments ( $c f$. Jégo and Pichavant, 2012). In addition, the attainment of equilibrium in our charges is strongly supported by the results of time-series runs performed by Bezmen et al. (1994) that show that gold equilibrates between sulfide and mafic/intermediate silicate melts after 30 hours at $1250^{\circ} \mathrm{C}$ and $4 \mathrm{kbar}$, for a silicate charge of $6 \mathrm{~mm}$ in diameter and $6 \mathrm{~mm}$ in height, weighing 300-350 mg (while our silicate charges weigh only $20-22 \mathrm{mg}$ ). For $\mathrm{H}_{2} \mathrm{O}$ in glasses, the difference-to-100 wt\% technique was adopted, which increases the error in comparison to direct measurements. However, numerous EPMA analyses of major elements were performed on each glass sample; standard deviations $( \pm \sigma)$ are generally $<1 \%$ (Table 2; Table S2), indicating homogeneity. Considering that glass powders were used as starting materials, the experimental durations in this study ( 100 hours) and the diffusivity data for of $\mathrm{H}_{2} \mathrm{O}$ in silicate melts of intermediate composition (Liu et al., 2004), water is certainly distributed homogeneously in the experimental glasses. Therefore, we conclude that our experimental phases are chemically homogeneous, a condition necessary for equilibrium.

Nevertheless, it should be emphasized that all experimental glasses in this study attained their final gold concentrations from the 'low concentration' side since gold concentrations in starting materials are lower than in experimental glasses. Gold solubility was in no case approached from the 'high concentration' side. In other words, gold concentration data from the present study have not been reversed. Yet, various lines of evidence, detailed below, suggest that the Au concentrations measured in the glasses can be considered as equilibrium solubilities at high $\mathrm{P}$ and $\mathrm{T}$ :

(1) Gold concentrations in the experimental glasses from this study vary by nearly a 
factor 400, ranging from 126 to $47771 \mathrm{ppb}$ (Table 2). Gold concentrations in glasses correlate with the experimental parameters ( $c f$. sections 4.4.1 and 4.4.2; see also Supplementary Information), so that the variations in gold concentrations between samples can be ascribed to differences either in $f_{2}$, melt $\mathrm{S}$ content, $\mathrm{aH}_{2} \mathrm{O}$ or melt composition. This would be unexpected if $\mathrm{Au}$ concentrations in glasses were influenced by kinetic factors. It is true, though, that the critical variables (e.g., $f \mathrm{O}_{2}, f \mathrm{~S}_{2}, \mathrm{~T}$ or $\mathrm{P}$ ) are generally involved in the derivation of the equilibrium constants. However, it is not established yet if they may potentially exert a control on the kinetics of reactions. In the literature there are no data that constrain the effect of such parameters on the diffusion rate of gold. Nevertheless, for instance, Watson (1994) reports a relatively small $\mathrm{fO}_{2}$ effect on the diffusion rate of sulfur, implying that the diffusing species and/or diffusion mechanism is relatively independent of $\mathrm{fO}_{2}$; on the other hand, Winther et al. (1998) conclude that the diffusion rate of reduced $\mathrm{S}$ species $\left(\mathrm{S}^{2-}, \mathrm{S}^{3-}\right)$ is significantly higher than that of oxidized $\mathrm{S}$ species $\left(\mathrm{SO}_{4}{ }^{2-}\right)$ in melt. In fact, it can be assumed that those variables might have a significant effect on the diffusion rate of gold during the first few minutes or hours of an experiment - i.e., well before the attainment of equilibrium - but they are very unlikely to be the cause of the observed correlations after almost 100 hours.

(2) In this study, a fast quench method was used systematically. No Au-nuggets were found in any charge, similarly to Zajacz et al. (2012) but contrary to most of previous gold solubility studies in presence of sulfur (e.g., Franck et al., 2002; Simon et al., 2007; Botcharnikov et al., 2010; Jégo et al., 2010; Jégo and Pichavant, 2012), in spite of similar quench rates and comparable Au solubility data. The absence of Au-nuggets could thus be related to the physical state of the system, i.e., a possible supercritical phase at high pressure. Therefore, the gold concentration of the melt did not suffer any modification during quench, 
implying that the $\mathrm{Au}$ concentration data reported unambiguously constrain gold concentrations in the melts at high pressure and temperature.

(3) Duplicate experiments were performed to check for reproducibility. Run 3 is a duplicate of run 1, and run 9 is a duplicate of run 2 (Table 2). In both cases, gold solubilities in the two duplicate experiments are mutually consistent and the results stress the direct dependence of gold solubilities with $\mathrm{fO}_{2}$.

In presence of sulfur, at $0.9 \mathrm{GPa}$, run 11 is a duplicate experiment of run 10. Although run 10 was quenched after 40 hours (due to technical problems), Bell et al. (2011) showed that $\mathrm{Au}$ contents in basalt at $1000{ }^{\circ} \mathrm{C}$ and $0.2 \mathrm{GPa}$ reach steady-state in about 24 hours, suggesting that Au10 charges actually reached thermodynamic equilibrium. It may be noted that melt Au contents in Au10 charges are 3 to 4 times lower than those in Au11 charges, though, but they nicely plot along the trends described by charges Au11 and 16. The lower gold solubility observed in Au10 charges is simply explained by lower $f \mathrm{O}_{2}(0.3-0.4 \log$ unit below the $f \mathrm{O}_{2}$ of run 11), lower melt S contents, lower NBO/T, and higher ASI due to slight differences in the amount of $\mathrm{H}_{2} \mathrm{O}$ and sulfur initially added during the preparation of the capsules ( $c f$. Table S5).

\subsection{Gold dissolution mechanism in S-free silicate melts}

Gold solubility in sulfur-free silicate melts has been previously shown to be essentially controlled by the redox state and the temperature (Borisov and Palme, 1996; Brenan et al., 2005; Jégo et al., 2010). At given temperature - which has a positive effect on Au dissolution in melt (e.g., Fig. 3a; Borisov and Palme, 1996) - and at least along a $f \mathrm{O}_{2}$ range relevant to 28 
most of magmatic systems (i.e., approximately $\log f \mathrm{O}_{2}>-12$ ), Au solubility increases with increasing $f \mathrm{O}_{2}$, generally with a slope close to 0.25 consistent with gold dissolving as $\mathrm{Au}^{1+}$ (or $\mathrm{Au}_{2} \mathrm{O}$ ) in the silicate melt (Brenan et al., 2005). $\mathrm{Au}_{2} \mathrm{O}_{3}\left(\right.$ or $\mathrm{Au}^{3+}$ ) is also a gold oxide commonly reported in the literature, but is considered to be more stable than $\mathrm{Au}^{1+}$ only in low-temperature $\left(<100^{\circ} \mathrm{C}\right)$, oxidizing environments (e.g., Borisov and Palme, 1996). Nonetheless, $\mathrm{Au}^{3+}$ was also proposed, together with metallic gold $\left(\mathrm{Au}^{0}\right)$, to be involved in the mechanism of $\mathrm{Au}$ dissolution in S-free melts at high $f \mathrm{O}_{2}$ (Jégo et al., 2010). Either way, the reaction describing the solution of gold in S-free silicate melts can be expressed by the following equilibrium:

$A u_{(\text {metal })}+\frac{x}{4} O_{2_{(g a s)}}=A u O_{x / 2_{(m e l t)}}$

where $\mathrm{AuO}_{\mathrm{x} / 2}$ (melt) stands for the gold oxide species dissolved in the silicate melt, and $\mathrm{x}$ represents the valence state of gold in solution.

The present study shows that melt gold solubility in absence of sulfur is not directly dependent on the hydration state of the melt $\left(\mathrm{aH}_{2} \mathrm{O}\right)$, neither on its iron content $\left(\mathrm{X}_{\mathrm{FeO}}\right)$ and major composition, nor on pressure. The temperature effect may be assessed in Fig. 3a where, at given $f \mathrm{O}_{2}$, melt gold concentrations decrease from 1400 to $1300{ }^{\circ} \mathrm{C}$, then $1050{ }^{\circ} \mathrm{C}$ and finally $1000{ }^{\circ} \mathrm{C}$. Apart from this, the new data obtained at 0.9 and $1.4 \mathrm{GPa}$ plot along the trend defined by the data at $0.4 \mathrm{GPa}$ (of similar melt compositions and experimental temperature), in a way that the entire data set seems to describe a slight positive slope along the $f \mathrm{O}_{2}$ range. Thus, the new data allow to confirm that gold solubility is positively correlated to $\mathrm{fO}_{2}$, so that gold dissolution in $\mathrm{S}$-free melts involves oxidized gold species as previously reported. But the key information brought up by this study is the absence of any pressure effect between 0.2 and $1.4 \mathrm{GPa}$ in sulfur-free systems. 


\subsection{Speciation and dissolution of sulfur}

The behavior of sulfur in silicate melts is known to be highly complex, especially because of the change of speciation from reduced sulfur (sulfide, $\mathrm{S}^{2-}$ ) to oxidized sulfur (sulfate, $\mathrm{SO}_{4}{ }^{2-}$ ) which occurs over a relatively narrow $f \mathrm{O}_{2}$ range, typically of $\sim 2-3 f \mathrm{O}_{2} \log$ units (e.g., Jugo et al., 2005; Baker and Moretti, 2011; Yang, 2012). A large number of studies -- among others, Jugo (2009) and Botcharnikov et al. (2011), showed that sulfur solubility increases rapidly with $\mathrm{fO}_{2}$ when $\mathrm{fO}_{2}$ is at the sulfide/sulfate transition, i.e. around $\sim \mathrm{NNO}-1$ to $\sim \mathrm{NNO}+3$ (depending on the pressure, temperature, melt water content and melt composition) (e.g., Baker and Moretti, 2011). The experimental data of Botcharnikov et al. (2011) also show that this increase in $\mathrm{S}$ solubility, from $\sim 100 \% \mathrm{~S}^{2-}$ in melt to $\sim 100 \% \mathrm{SO}_{4}{ }^{2-}$ in melt, is smaller in amplitude and suggest that the sulfide/sulfate transition is shifted towards higher $\mathrm{fO}_{2}$ in andesitic melts compared to basaltic melts. Moreover, when the melt $\mathrm{S}$ concentration data of Jégo and Pichavant (2012) at $0.4 \mathrm{GPa}$ are plotted against $\mathrm{fO}_{2}$ together with those of Botcharnikov et al. (2011) (Fig. 6a), the moderately and very oxidized charges of Jégo and Pichavant (2012) describe a similar increasing trend, but even smaller and more shifted towards higher $f \mathrm{O}_{2}$ than the andesitic charges of Botcharnikov et al. (2011). In detail, sulfur contents in basaltic melts at $0.2 \mathrm{GPa}$ increase from $\sim 700 \mathrm{ppm}$ at $\sim \mathrm{NNO}-1$ up to 6000 ppm at $\mathrm{NNO}+1.25$, while sulfur contents in andesitic melts at $0.2 \mathrm{GPa}$ increase from $\sim 500$ ppm at $\sim \mathrm{NNO}-0.5$ up to $3000 \mathrm{ppm}$ at $\mathrm{NNO}+1.5$, and sulfur contents in dacitic melts at 0.4 GPa increase from $\sim 400 \mathrm{ppm}$ at $\mathrm{NNO}+1.25$ up to $>2000 \mathrm{ppm}$ at $\Delta \mathrm{NNO}>3$. Thus, considering the important $f \mathrm{O}_{2}$ gap between the sulfide/sulfate transition of andesitic melts at $0.2 \mathrm{GPa}$ (occurring at $\sim \mathrm{NNO}+0.8$; Fig. 6a) and that of dacitic melts at $0.4 \mathrm{GPa}$ (occurring at 30 
$\sim \mathrm{NNO}+1.6$ ), in comparison to the significant but less important $f \mathrm{O}_{2}$ gap between those of basaltic and andesitic melts at $0.2 \mathrm{GPa}\left(\sim 0.4 \log f \mathrm{O}_{2}\right.$ unit difference; Fig. 6a), it can be proposed that the sulfide/sulfate transition is not only shifted towards higher $f \mathrm{O}_{2}$ when the degree of melt polymerization increases, but it also is when pressure increases. It is worth noting that these suggestions correspond exactly to what is predicted by the model of Moretti and Baker (2008) (cf. Fig. 13 of Baker and Moretti, 2011) about the position of the sulfide/sulfate transition relative to $\mathrm{fO}_{2}$, i.e., the sulfide/sulfate transition appears to be shifted towards higher $f \mathrm{O}_{2}$ when pressure and the degree of melt polymerization increase. The authors explain these modeling predictions by compositional and pressure effects on the activities of the sulfide and sulfate species dissolved in the melt. In addition, this hypothesis is also consistent with the fact that the SCSS (Sulfur Concentration at Sulfide Saturation) and the SCAS (Sulfur Concentration at Anhydrite Saturation) decrease with increasing degree of melt polymerization (Holzheid and Grove, 2002; Yang, 2012; Zajacz et al., 2013; Zajacz, 2015). Therefore, the respective dataset of Botcharnikov et al. (2011) and Jégo and Pichavant (2012) seem to be mutually consistent to each other. One could argue that the moderately oxidized charges of Jégo and Pichavant (2012), spanning a $f \mathrm{O}_{2}$ range between $\mathrm{NNO}+1.25$ to $\mathrm{NNO}+2$, are too oxidized to be considered as sulfide-dominated melts and should rather be seen as sulfate-dominated ones. However, (1) those charges are clearly pyrrhotite-saturated and no trace of anhydrite was found (Jégo and Pichavant, 2012), (2) when the melt sulfur content of those charges is estimated by using either the SCSS model of Fortin et al. (2015) or the SCAS models of Li and Ripley (2009) or Baker and Moretti (2011) (both SCAS models give similar results), all data points are well reproduced (within $20 \%$ uncertainty) by the SCSS model, whereas they are overestimated by a factor of 2 to 3 by both SCAS models (Fig. $5 b)$, and (3) as mentioned above, the oxidation state of sulfur in melt of charge C1C was 
determined by using the $\mathrm{SK} \alpha$ peak shift method on the electron microprobe, and the results confirmed that sulfur is mostly expressed as $\mathrm{S}^{2-}$ in this glass ( $c f$. Fig. S1).

Regarding the new, high pressure charges of the present study and the reduced charges of Jégo and Pichavant (2012), a different interpretation must be made because they span a $f \mathrm{O}_{2}$ range significantly too reduced and too far away from the sulfide/sulfate transition (given their dacitic composition and respective pressure) to be following a dissolution process similar to that described above. In other words, sulfur is dissolved in melt most likely as $\mathrm{S}^{2-}$ in all those reduced charges, as confirmed by the oxidation state of sulfur (i.e., $S^{2-}$ ) measured in charges C4E and C1C of Jégo and Pichavant (2012), which charges surround the new high pressure charges in terms of $f \mathrm{O}_{2}(c f$. Fig. S1). Besides, the melt $\mathrm{S}$ concentrations show a moderate increase with $f \mathrm{O}_{2}$ in those reduced charges (for given melt composition and pressure), some of them are relatively $\mathrm{FeO}_{\mathrm{T}}$-poor but they fractionated a significant proportion of pyrrhotite, and all of them are $\mathrm{H}_{2} \mathrm{~S}$-rich. It is known that in hydrous felsic melts, $\mathrm{H}_{2} \mathrm{~S}$ is the dominant sulfur vapor species when $f_{2}<\mathrm{FMQ}+1$ (Carroll and Webster, 1994), and that $\mathrm{S}$ dissolution may be attributed to the following reactions:

$$
\begin{aligned}
& \mathrm{H}_{2} \mathrm{~S}_{(\text {gas })}+\mathrm{FeO}_{(\text {melt })}+\mathrm{O}^{2-}{ }_{(\text {melt })}=\mathrm{FeS}_{(\text {melt })}+2 \cdot \mathrm{OH}_{(\text {melt })}^{-} \\
& \mathrm{H}_{2} \mathrm{~S}_{(\mathrm{gas})}+\mathrm{FeO} \mathrm{O}_{(\text {melt })}=\mathrm{FeS}_{(\text {melt })}+\mathrm{H}_{2} \mathrm{O}_{(\text {gas })}
\end{aligned}
$$

However, these reactions suggest that sulfide solubility in silicate melt is proportional to $\mathrm{FeO}$ activity, and is negatively correlated with $\mathrm{H}_{2} \mathrm{O}$ fugacity, which is roughly observed for $\mathrm{FeO}$ activity in Fig. S5a, but not for $\mathrm{H}_{2} \mathrm{O}$ fugacity since melt $\mathrm{S}$ contents and $a \mathrm{H}_{2} \mathrm{O}$ are positively correlated in Fig. S3. Instead, it may be proposed that the reaction of S dissolution in the new, high pressure charges and the reduced charges of Jégo and Pichavant (2012) is 
similar to the mechanism described by Bradbury (1983) about the dissolution of pyrrhotite (Po) in water-saturated albitic melts:

$\mathrm{FeS}_{(\mathrm{Po})}+\mathrm{O}^{2-}{ }_{(\mathrm{melt})}+\mathrm{H}_{2} \mathrm{O}_{(\mathrm{gas})}=\mathrm{FeO}_{(\mathrm{melt})}+\mathrm{SH}_{(\text {melt })}^{-}+\mathrm{OH}_{(\mathrm{melt})}$

Indeed, this reaction predicts that the solubility of sulfur will be enhanced by increasing $f \mathrm{O}_{2}$ and $\mathrm{aH}_{2} \mathrm{O}$, which is consistent with our observations.

5.4 Gold dissolution mechanism in S-bearing silicate melts

The behavior of gold in sulfur-bearing silicate melts has previously been shown to be mainly controlled by $f \mathrm{O}_{2}$, temperature, and melt $\mathrm{S}$ concentration (or $f \mathrm{~S}_{2}$ ) (e.g., Botcharnikov et al., 2010; Jégo and Pichavant, 2012). In particular, the experimental results of Botcharnikov et al. (2011) show that gold solubility is highest within a narrow window of redox conditions corresponding to the sulfide/sulfate transition. These authors report that gold concentration increases continuously by almost one order of magnitude with increasing $f \mathrm{O}_{2}$ from $\sim$ FMQ-0.5 (corresponding to $\sim \mathrm{NNO}-1.2$ at $0.2 \mathrm{GPa}$ and $1050^{\circ} \mathrm{C}$ ) up to a maximum at $\sim \mathrm{FMQ}+1 \quad(\sim \mathrm{NNO}+0.3)$, then drops rapidly at more oxidizing conditions to reach the concentration level of $\mathrm{S}$-free samples at $\sim \mathrm{FMQ}+2(\sim \mathrm{NNO}+1.3)$. Interestingly, they observe that the highest Au solubility occurs in melts containing sulfur dissolved as both sulfide and sulfate, and that the maximum $\mathrm{Au}$ concentration is reached in melts with the highest concentration of dissolved $\mathrm{S}^{2-}$ species, but not in melts with the highest total S content. This suggests that, at $f \mathrm{O}_{2} \leq \mathrm{NNO}+0.5$, gold is incorporated in silicate melts mainly by complexation with $\mathrm{S}^{2-}$, and confirms the role of $f \mathrm{~S}_{2}$ in governing Au dissolution in moderately oxidizing conditions. At more oxidizing conditions, all sulfur is dissolved as $\mathrm{SO}_{4}{ }^{2-}$, which does not favor Au dissolution. Nevertheless, some important clarification may be made when 
looking at Fig. $6 \mathrm{~b}$ in which the data of Botcharnikov et al. (2011) are plotted versus $f \mathrm{O}_{2}$ together with those of Jégo and Pichavant (2012) and the new data of the present study. It can be noticed that the melt gold concentration data of Botcharnikov et al. (2011) at 0.2 GPa show some differences depending whether the melt composition is basaltic or andesitic. Indeed, the maximum Au concentration observed in andesitic melts is lower (by $2000 \mathrm{ppb} \mathrm{Au}$ ) and shifted towards more oxidizing conditions (by $\sim 0.5 \log f \mathrm{O}_{2}$ unit) than the maximum $\mathrm{Au}$ concentration observed in basaltic melts. In addition, the maximum $\mathrm{Au}$ concentration observed in dacitic melts at $0.4 \mathrm{GPa}$ and moderately oxidizing conditions is even lower (by $\sim 4000 \mathrm{ppb} \mathrm{Au}$ ) and shifted towards even more oxidizing conditions (by $\sim 1 \log f \mathrm{O}_{2}$ unit) compared to the maximum Au concentration observed in andesitic melts at lower pressure. These observations are consistent with those made in the previous section about sulfur dissolution, which suggest that (1) the sulfide/sulfate transition is shifted towards more oxidizing conditions with increasing pressure and degree of melt polymerization, (2) the maximum melt Au concentration in relatively oxidizing conditions is directly linked to the melt $\mathrm{S}^{2-}$ concentration, which itself is partly controlled by $\mathrm{fO}_{2}$, pressure and melt composition, and (3) pressure has an indirect, negative effect on $\mathrm{Au}$ solubility. Therefore, in moderately oxidizing conditions and at given temperature, the dissolution of gold in Fe-bearing silicate melts at sulfide saturation is a highly complex interplay of $f \mathrm{O}_{2}, f \mathrm{~S}_{2}$, pressure and melt composition (including S concentration), and further systematic experimental work is needed to better constrain the solubility mechanism of gold. As previously noted by Botcharnikov et al. (2011) and confirmed here by the moderately oxidized data of Jégo and Pichavant (2012), the relative increase in the concentration of dissolved $S^{2-}$ is only $\sim 1 / 3$ of the relative increase in $\mathrm{Au}$ concentration, indicating that $\mathrm{Au}$-components in silicate melts may include $\mathrm{O}$ in 34 
addition to S (i.e., Au-S-O-bearing components). Nevertheless, the absolute concentration of $\mathrm{S}^{2-}$ is about 3 orders of magnitude higher than the absolute concentration of Au (since $\mathrm{S}^{2-}$ reacts mainly with $\mathrm{Fe}$ in the melt), which suggests that Au may potentially be incorporated in melt by formation of Au-Fe-S-O-bearing components, as already hypothesized in the thermodynamic model of Jégo and Pichavant (2012). Thus, the apparent agreement of results between these two studies stresses the need for future spectroscopic analyses to test the presence of such components in sulfide-saturated, Fe-bearing silicate melts.

In reducing conditions (i.e., where $\mathrm{S}^{2-} / \mathrm{S}_{\text {total }} \sim 1$ ), the mechanism of gold dissolution in sulfide-saturated, Fe-bearing silicate melts seems simpler because all dissolved sulfur is expressed as sulfide. As explained above in section 5.3, sulfur dissolution in reduced melts at given temperature appears to be governed by a complex interplay between $f \mathrm{O}_{2}, a \mathrm{H}_{2} \mathrm{O}, \mathrm{X}_{\mathrm{FeO}}$, pressure and melt composition/structure. The reduced $\mathrm{Au}$ solubility data of Jégo and Pichavant (2012) at $0.4 \mathrm{GPa}$ and those of the present study at 0.9 and $1.4 \mathrm{GPa}$ follow the same trends than those defined by the sulfur solubility data (Fig. 6). Therefore, it can be suggested that $\mathrm{Au}$ is incorporated in melts by complexation with $\mathrm{S}^{2-}$. However, here again, it can be observed that the relative increase in Au concentration is significantly higher than the relative increase in $\mathrm{S}$ (or $\mathrm{S}^{2-}$ ) concentration, and that the absolute concentrations of $\mathrm{S}$ are about 3 orders of magnitude higher than those of Au. This may indicate the involvement of Au-Fe-SO-bearing components in the dissolution process of gold, yet to be confirmed by spectroscopic studies though. In summary, it may be argued that the main parameters controlling gold solubility in reduced sulfide-saturated, Fe-bearing silicate melts at given temperature are the melt sulfur concentration and $f \mathrm{O}_{2}$, whereas the other parameters $\left(\mathrm{X}_{\mathrm{FeO}}\right.$, $a \mathrm{H}_{2} \mathrm{O}$, melt composition, and pressure) only have indirect effects on Au solubility via their respective control on sulfur dissolution. 


\section{IMPLICATIONS FOR AU-ENRICHMENT IN RISING MAGMAS}

The results of the present study indicate that pressure has no direct, detectable effect on gold solubility in sulfur-free and sulfur-bearing silicate melts. Nevertheless, our results confirm that pressure has a strong, negative effect on sulfur solubility, and suggest that pressure - together with the degree of melt polymerization - has a significant effect on the $f \mathrm{O}_{2}$ range at which the sulfide/sulfate transition occurs ( $c f$. Fig. 6a). Since Au solubility is closely related to the abundance of sulfide $\left(\mathrm{S}^{2-}\right)$ species in melt in reducing and moderately oxidizing conditions, the influence of pressure on Au dissolution is indirect but effective and important in sulfide-saturated silicate melts.

Now, let us assume for the rest of the discussion that the hypothesis formulated above, according to which the sulfide-sulfate transition is shifted towards higher $f \mathrm{O}_{2}$ with increasing pressure and degree of melt polymerization, is proven. In their model of sulfide-saturated mantle melting, Botcharnikov et al. (2011) calculated that the highest Au enrichment is observed in melts at low degrees of melting $(\leq 5 \%)$ and that the Au concentration in the melt may be higher than that in the source by a factor 10-30 at $f \mathrm{O}_{2}$ between FMQ (corresponding to $\sim \mathrm{NNO}$ at $\mathrm{P}>1.4 \mathrm{GPa}$ and $\left.1050^{\circ} \mathrm{C}\right)$ to $\mathrm{FMQ}+1(\sim \mathrm{NNO}+1)$, i.e. near or at the sulfide-sulfate transition in the mantle wedge. Such an enrichment necessitates that sulfides in the mantle residue are almost completely consumed. However, except for correcting the solubility of sulfur in basaltic melt, this model does not consider any potential effect of pressure on the position of the sulfide-sulfate transition in melt with respect to $f \mathrm{O}_{2}$. Now, if we suppose that the sulfide-sulfate transition in mantle melts is shifted towards significantly more oxidizing 36 
conditions than FMQ+1 at pressures relevant to mantle wedge melting ( > 1 GPa) (cf. Fig. 6), then, at the moderately oxidizing $f \mathrm{O}_{2}$ conditions thought to be prevailing in the mantle wedge (FMQ+0.5 to FMQ+1.4; Jugo et al., 2010), the primary mantle melts are expected to be in equilibrium with very stable sulfide phases (possibly in the liquid form at the $P-T$ conditions of the upper mantle, but still stable; e.g., Li and Audétat, 2012). Therefore, even after 5\% mantle melting, the major part of the bulk amount of gold initially present in the upper mantle will likely remain locked in the sulfide phases in equilibrium with a Au-poor primary mantle melt (all the more if the sulfide phases are liquid, compared to monosulfide solid solutions; Li and Audétat, 2012). Then, either these sulfides remain at depth in the source region (owing to their high density) and leave a Au-poor buoyant melt, or they are entrained with the melt to shallower levels. In the latter case, either we assume that the $f \mathrm{O}_{2}$ of the magmatic system remains roughly constant during ascent of the magma through the arc crust (before stalling and fractionation) or that it may become more reducing owing to early decompressioninduced degassing. In any way, the decreasing pressure would lead to shift the sulfide-sulfate transition back to more reducing conditions. If this shift is sufficient to cross the $f \mathrm{O}_{2}$ of the melt, the sulfides are supposed to destabilize and sulfates may form instead, liberating all gold in the silicate melt. This is one interesting consequence of the potential influence of pressure, which may favor gold enrichment in arc magmas. But even if the shift of the sulfide-sulfate transition does not cross the $f \mathrm{O}_{2}$ of the melt, the decreasing pressure would increase the solubility of sulfur in melt and dissolve part of the sulfides, leading to the release of a certain amount of gold into the silicate melt.

Once magma fractionation occurs within the crust, the $f \mathrm{O}_{2}$ of the magmatic system is expected to vary to some extent. However, whether $\mathrm{fO}_{2}$ will evolve towards more oxidizing or more reducing conditions is function of several, possibly conflicting parameters. For example, 
early fractionation of olivine will tend to slightly oxidize the melt whereas fractionation of $\mathrm{Fe}^{3+}$-rich oxides will lead to reduce the residual melt. Also, at shallow levels, it is generally thought that silicate melts will be oxidized during degassing/exsolution of the aqueous ore fluid (by “self-oxidation”; Candela, 1986) while Burgisser and Scaillet (2007) mostly predict a reduction of the magma redox state during decompression of a rhyolite melt coexisting with a H-O-S gas (although rhyolitic magmas are generally not considered as the parent magmas of porphyry and/or epithermal ore deposits). In addition, decreasing pressure and magma evolution are supposed to be constantly competing since decreasing pressure would tend to destabilize sulfides and increase sulfur (and gold) solubility, and thus favor gold release to the melt, whereas magma evolution towards more felsic compositions would stabilize sulfides and increase the degree of melt polymerization, thus decreasing sulfur (and gold) solubility and favoring gold sequestration. Therefore, the sole effect of pressure on Au solubility during magma ascent is expected to be limited by the influence of other parameters, notably by the variation of $f \mathrm{O}_{2}$ and melt composition during magma evolution, and the effect of temperature. This stresses the need for further systematic experimental and analytical work to better constrain the role of each variable on the gold budget of an ascending magma.

In the case where mantle melting occurs in reducing conditions (i.e., $S^{6+} / S_{\text {total }} \sim 0$ ), only a small amount of sulfides may be consumed in the source, so the primary melts will be Au-poor. The effect of decreasing pressure during magma ascent would favor the attainment of the sulfide-sulfate transition, but no further Au-enrichment will be expected in a closed magmatic system. This might explain why major gold deposits are commonly associated with subduction-related magmas rather than other magmatic systems which are supposedly less oxidized (e.g., Gaillard et al., 2015).

38 
In the case where mantle melting occurs in very oxidizing conditions (i.e., $S^{6+} / S_{\text {total }} \sim$ 1), the Au-enrichment of the melt will be limited by the dissolution of gold through the formation of Au-oxide species, corresponding to the solubility of gold in S-free melts (which can be relatively high, around $\sim 600 \mathrm{ppb} \mathrm{Au}$ ). The effect of decreasing pressure during magma ascent would extend the field of sulfide instability and contribute to maintain the melt $\mathrm{Au}$ concentration to a level sufficient enough to form Au-enriched porphyries.

Finally, if we consider subducting slab melting instead of mantle wedge melting (since our starting materials are adakitic rocks; $c f$. Kimura et al., 2014), it can be expected that (1) the primary melt composition will be intermediate to felsic (typically dacitic to rhyolitic; e.g., Rapp and Watson, 1995), (2) the pressure conditions of slab melting will be higher than those of mantle melting, and the temperature conditions will be lower, and (3) the partial melting of the hydrothermally altered oceanic crust will likely occur at sulfide saturation (Jégo and Dasgupta, 2014). Therefore, if we try to combine these assumptions with the information available in Fig. 6, the primary slab melts are supposed to be sulfide-saturated and relatively sulfur-poor (e.g., < 1000 ppm S). In this case, the initial gold budget of the primary slab melts will also be rather low $(<3000 \mathrm{ppb} \mathrm{Au})$ and most of it will be sequestered into the sulfide phase in equilibrium with the melt. Then, during ascent of the slab melts through the mantle wedge and the arc crust, and subsequent fractional crystallization, the story is expected to be relatively similar to that of mantle melts. Hence, slab partial melts do not seem to be the most efficient carriers of gold among subduction-related magmas.

\section{CONCLUSIONS}

We have experimentally determined the solubility of gold in sulfur-free and sulfide- 
saturated hydrous dacitic melts at $1000^{\circ} \mathrm{C}, 0.9$ and $1.4 \mathrm{GPa}$, and $f \mathrm{O}_{2} \sim$ NNO. In sulfur-free melts, Au concentrations range from 82 to $225 \mathrm{ppb}$ at $0.9 \mathrm{GPa}$, and the two charges at 1.4 $\mathrm{GPa}$ contain respectively 68 and $142 \mathrm{ppb} \mathrm{Au}$ in melt. In sulfide-saturated melts, $\mathrm{Au}$ concentrations range from 813 to $6583 \mathrm{ppb}$ at $0.9 \mathrm{GPa}$, and the four charges at $1.4 \mathrm{GPa}$ contain between 363 ppb to almost 48 ppm Au in melt.

By comparing our results to previous experimental studies at lower pressures and variable redox conditions, it appears that:

- in S-free silicate melts, $\mathrm{Au}$ solubility is a function of $f \mathrm{O}_{2}$ and temperature only, and the reaction describing the dissolution of gold can be expressed by the following equilibrium:

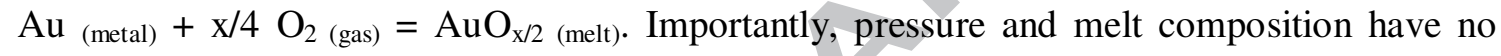
detectable effect on Au dissolution.

- in sulfide-saturated silicate melts, the behaviour of gold is mainly a function of $\mathrm{fO}_{2}$, melt sulfur concentration and temperature. Interestingly, pressure has no direct effect on $\mathrm{Au}$ solubility, but it has a strong, negative effect on S solubility. Since Au dissolution is closely related to $S^{2-}$ behaviour in reducing $\left(S^{6+} / S_{\text {total }} \sim 0\right)$ and moderately oxidizing $\left(S^{6+} / S_{\text {total }}<0.5\right)$ conditions, pressure has a significant but indirect effect on Au solubility via S solubility. This is also true for the other parameters influencing sulfur dissolution $\left(\mathrm{X}_{\mathrm{FeO}}, a \mathrm{H}_{2} \mathrm{O}\right.$, melt composition).

In addition, we propose that the transition from sulfide $\left(\mathrm{S}^{2-}\right)$ to sulfate $\left(\mathrm{S}^{6+}\right)$ species in melt is shifted towards more oxidizing conditions when pressure and the degree of melt polymerization increase, although this needs to be proven in future studies. If this is true, this may have important consequences during mantle melting (sequestration of gold from the sulfide-saturated primary melt) and magma ascent (destabilization of sulfides and release of 40 
gold to the silicate melt). However, at shallow levels, decreasing pressure, magma evolution, and varying redox conditions would be continuously competing to concentrate or fractionate gold.

Acknowledgements

This study forms part of a postdoctoral fellowship of the first author and was partially supported by the National Science Council of Taiwan (YI: NSC 99-2116-M-001-013), the Institute of Earth Sciences, Academia Sinica, Taipei (Taiwan) and the GCOE Program for Earth Sciences (Tohoku University, Japan). S. Jégo would like to acknowledge T.C. Liu (NTNU, Taipei, Taiwan) for the free access to the piston cylinder equipment he is in charge of. GFZ acknowledges funding through Academia Sinica and the National Science Council of Taiwan (NSC grant 97-2628-M-001-027-MY2) during the experimental period of this study.

\section{REFERENCES}

Aries, S., Valladon, M., Polvé, M. and Dupré B. (2000) A routine method for oxide and hydroxide interference corrections in ICPMS chemical analysis of environmental and geological samples. Geostand. Newslett. 24, 19-31.

Baker, D.R. and Moretti, R. (2011) Modeling the solubility of sulfur in magmas: A 50-year 
old geochemical challenge. Rev. Mineral. Geochem. 73, 167-213.

Bell, A.S., Simon, A. and Guillong, M. (2009) Experimental constraints on Pt, Pd and Au partitioning and fractionation in silicate melt-sulfide-oxide-aqueous fluid systems at 800 ${ }^{\circ} \mathrm{C}, 150 \mathrm{MPa}$ and variable sulfur fugacity. Geochim. Cosmochim. Acta 73, 5778-5792.

Bell, A.S., Simon, A. and Guillong, M. (2011) Gold solubility in oxidized and reduced, watersaturated mafic melt. Geochim. Cosmochim. Acta 75, 1718-1732.

Bellon, H. and Yumul, G. P., Jr. (2000) Mio-Pliocene magmatism in the Baguio Mining District (Luzon, Philippines): Age clues to its geodynamic setting. C. R. Acad. Sci. Paris, 331, 295-302.

Bellon, H. and Yumul, G. P., Jr. (2001) Miocene to Quaternary adakites and related rocks in Western Philippine arc sequences. C. R. Acad. Sci. Paris, 333, 343-350.

Bezmen, N.I., Asif, M., Brügmann, G.E., Romanenko, I.M. and Naldrett, A.J. (1994) Distribution of $\mathrm{Pd}, \mathrm{Rh}, \mathrm{Ru}, \mathrm{Ir}, \mathrm{Os}$, and $\mathrm{Au}$ between sulfide and silicate melts. Geochim. Cosmochim. Acta 58, 1251-1260.

Borisov, A. and Palme, H. (1996) Experimental determination of the solubility of $\mathrm{Au}$ in silicate melts. Mineral. Petrol. 56, 297-312.

Borisova, A.Y., Pichavant, M., Polvé, M., Wiedenbeck, M., Freydier, R. and Candaudap, F. (2006) Trace element geochemistry of the 1991 Mt. Pinatubo silicic melts, Philippines: Implications for ore-forming potential of adakitic magmatism. Geochim. Cosmochim. Acta, 70, 3702-3716.

Botcharnikov, R.E., Linnen, R.L. and Holtz, F. (2010) Solubility of Au in Cl- and S-bearing hydrous silicate melts. Geochim. Cosmochim. Acta 74, 2396-2411.

Botcharnikov, R.E., Linnen, R.L., Wilke, M., Holtz, F., Jugo, P.J. and Berndt, J. (2011) High 42 
gold concentrations in sulphide-bearing magma under oxidizing conditions. Nature Geoscience 4, 112-115.

Bradbury, J.W. (1983) Pyrrhotite solubility in hydrous albite melts. Ph. D. dissertation, Penn. State Univ.

Brenan, J.M., McDonough, W.F. and Ash, R. (2005) An experimental study of the solubility and partitioning of iridium, osmium and gold between olivine and silicate melt. Earth Planet. Sci. Lett. 237, 855-872.

Bureau, H. and Keppler, H. (1999) Complete miscibility between silicate melts and hydrous fluids in the upper mantle: experimental evidence and geochemical implications. Earth Planet. Sci. Lett. 165, 187-196.

Burgisser, A. and Scaillet, B. (2007) Redox evolution of a degassing magma rising to the surface. Nature 445, 194-197.

Burkemper, L.K. and Agee, C.B. (2010) The effect of pressure and temperature on molybdenum solubility in silicate melts. $41^{\text {st }}$ Lunar and Planetary Science Conference.

Burnham, C.W. (1979) The importance of volatile constituents. In The evolution of the igneous rocks: Fiftieth anniversary perspectives - Chapter 16. Princeton University Press pp.439.

Candela, P.A. (1986) The evolution of vapor from silicate melts: Effect on oxygen fugacity. Geochimica et Comochimica Acta 50, 1205-1211.

Carroll, M.R. and Webster, J.D. (1994) Solubilities of sulfur, noble gases, nitrogen, chlorine, and fluorine in magmas. Rev. Mineral. 30, 231-279.

Chou, I.-M. (1986) Permeability of precious metals to hydrogen at $2 \mathrm{~kb}$ total pressure and elevated temperatures. Am. J. Science 286, 638-658.

Crocket, J.H., Fleet, M.E. and Stone, W.E. (1997) Implications of composition for 
experimental partitioning of platinum-group elements and gold between sulfide liquid and basalt melt: The significance of nickel content. Geochim. Cosmochim. Acta 61, 41394149.

Defant, M.J. and Drummond, M.S. (1990) Derivation of some modern arc magmas by melting of young subducted lithosphere. Nature 347, 662-665.

Ertel, W., Walter, M.J., Drake, M.J. and Sylvester, P.J. (2006) Experimental study of platinum solubility in silicate melt to $14 \mathrm{GPa}$ and $2273 \mathrm{~K}$ : Implications for accretion and core formation in Earth. Geochim. Cosmochim. Acta 70, 2591-2602.

Fleet, M.E., Crocket, J.H. and Stone, W.E. (1996) Partitioning of platinum-group elements (Os, Ir, Ru, Pt, Pd) and gold between sulfide liquid and basalt melt. Geochim. Cosmochim. Acta 60, 2397-2412.

Fleet, M.E., Crocket, J.H., Liu, M. and Stone, W.E. (1999) Laboratory partitioning of platinum-group elements (PGE) and gold with application to magmatic sulfide-PGE deposits. Lithos 47, 127-142.

Fortin, M.-A., Riddle, J., Desjardins-Langlais, Y. and Baker, D.R. (2015) The effect of water on the sulfur concentration at sulfide saturation (SCSS) in natural melts. Geochim. Cosmochim. Acta 160, 100-116.

Frank, M.R., Candela, P.A., Piccoli, P.M. and Galscock, M.D. (2002) Gold solubility, speciation and partitioning as a function of $\mathrm{HCl}$ in the brine-silicate melt-metallic gold system at $800^{\circ} \mathrm{C}$ and $100 \mathrm{MPa}$. Geochim. Cosmochim. Acta 66, 3719-3732.

Gaillard, F., Scaillet, B., Pichavant, M. and Iacono-Marziano, G. (2015) The redox geodynamics linking basalts and their mantle sources through space and time. Chem. 44

Geol., in press, 17 p. $<10.1016 /$ j.chemgeo.2015.07.030> 
Gunter, M.D., Myers, J. and Girsperberg, S. (1987) Hydrogen: Metal membranes. In Hydrothermal experimental techniques, H.L. Barnes and G.C. Ulmer (Eds.), Wiley, New York, p.100-120.

Holzheid, A. and Grove, T.L. (2002) Sulfur saturation limits in silicate melts and their implications for core formation scenarios for terrestrial planets. Am. Mineral. 87, 227-237.

Imai, A. (2001) Generation and evolution of ore fluids for porphyry $\mathrm{Cu}$-Au mineralization of the Santo Tomas II (Philex) deposit, Philippines. Res. Geol. 51, 71-96.

Imai, A. (2002) Metallogenesis of porphyry $\mathrm{Cu}$ deposits of the western Luzon arc, Philippines: $\mathrm{K}-\mathrm{Ar}$ ages, $\mathrm{SO}_{3}$ contents of microphenocrystic apatite and significance of intrusive rocks. Res. Geol. 52, 147-161.

Jégo, S. and Pichavant, M. (2012) Gold solubility in arc magmas: Experimental determination of the effect of sulfur at $1000^{\circ} \mathrm{C}$ and $0.4 \mathrm{GPa}$. Geochim. Cosmochim. Acta 84, 560-592.

Jégo, S. and Dasgupta, R. (2014) The fate of sulfur during fluid-present melting of subducting basaltic crust at variable oxygen fugacity. J. Petrol. 55, 1019-1050.

Jégo, S., Maury, R.C., Polvé, M., Yumul, Jr., G.P., Bellon, H., Tamayo, Jr., R.A. and Cotten, J. (2005) Geochemistry of adakites from the Philippines : Constraints on their origins. Res. Geol. 55, 163-187.

Jégo, S., Pichavant, M. and Mavrogenes, J.A. (2010) Controls on gold solubility in arc magmas: An experimental study at $1000^{\circ} \mathrm{C}$ and 4 kbar. Geochim. Cosmochim. Acta 74 , 2165-2189.

Jenner, F.E., O'Neill, H.St.C., Arculus, R.J. and Mavrogenes, J.A. (2010) The magnetite crisis in the evolution of arc-related magmas and the initial concentration of $\mathrm{Au}, \mathrm{Ag}$ and $\mathrm{Cu}$. J. Petrol. 51, 2445-2464.

Jugo, P.J. (2009) Sulfur content at sulfide saturation in oxidized magmas. Geology 37, 415- 
418.

Jugo, P.J., Candela, P.A. and Piccoli, P.M. (1999) Magmatic sulfides and Au:Cu ratios in porphyry deposits: an experimental study of copper and gold partitioning at $850^{\circ} \mathrm{C}, 100$ MPa in a haplogranitic melt-pyrrhotite-intermediate solid solution-gold metal assemblage, at gas saturation. Lithos 46, 573-589.

Jugo, P.J., Luth, R.W. and Richards, J.P. (2005) Experimental data on the speciation of sulfur as a function of oxygen fugacity in basaltic melts. Geochim. Cosmochim. Acta 69, 497503.

Jugo, P.J., Wilke, M. and Botcharnikov, R.E. (2010) Sulfur K-edge XANES analysis of natural and synthetic basaltic glasses: Implications for $\mathrm{S}$ speciation and $\mathrm{S}$ content as function of oxygen fugacity. Geochim. Cosmochim. Acta 74, 5926-5938.

Kesler, S.E., Chryssoulis, S.L. and Simon, G. (2002) Gold in porphyry deposits: its abundance and fate. Ore Geol. Rev. 21, 103-124.

Kimura, J.-I., Gill, J.B., Kunikiyo, T., Osaka, I., Shimoshioiri, Y., Katakuse, M., Kakubuchi, S., Nagao, T., Furuyama, K., Kamei, A., Kawabata, H., Nakajima, J., van Keken, P.E. and Stern, R.J. (2014) Diverse magmatic effects of subducting a hot slab in SW Japan: Results from forward modeling. Geochem. Geophys. Geosyst. 15, 691-739.

Klimm, K., Kohn, S.C., O'Dell, L.A., Botcharnikov, R.E. and Smith, M.E. (2012) The dissolution mechanism of sulphur in hydrous silicate melts. I: Assessment of analytical techniques in determining the sulphur speciation in iron-free to iron-poor glasses. Chem. Geol. 322-323, 237-249.

Kress, V.C. and Carmichael, I.S.E. (1991) The compressibility of silicate liquids containing $\mathrm{Fe}_{2} \mathrm{O}_{3}$ and the effect of composition, temperature, oxygen fugacity and pressure on their 46 
redox states. Contrib. Mineral. Petrol. 108, 82-92.

Li, Y. and Audétat, A. (2012) Partitioning of V, Mn, Co, Ni, Cu, Zn, As, Mo, Ag, Sn, Sb, W, $\mathrm{Au}, \mathrm{Pb}$, and $\mathrm{Bi}$ between sulfide phases and hydrous basanite melt at upper mantle conditions. Earth Planet. Sci. Lett. 355-356, 327-340.

Li, C. and Ripley, E.M. (2009) Sulfur contents at sulfide-liquid or anhydrite saturation in silicate melts: Empirical equations and example applications. Econ. Geol. 104, 405-412.

Linnen, R.L., Pichavant, M., Holtz, F. and Burgess, S. (1995) The effect of $f \mathrm{O}_{2}$ on the solubility, diffusion, and speciation of tin in haplogranitic melt at $850^{\circ} \mathrm{C}$ and $2 \mathrm{kbar}$. Geochim. Cosmochim. Acta 59, 1579-1588.

Liu, Y., Zhang, Y. and Behrens, H. (2004) $\mathrm{H}_{2} \mathrm{O}$ diffusion in dacitic melts. Chem. Geol. 209, 327-340.

Liu, Y., Samaha, N.-T. and Baker, D.R. (2007) Sulfur concentration at sulfide saturation (SCSS) in magmatic silicate melts. Geochim. Cosmochim. Acta 71, 1783-1799.

Martel, C., Pichavant, M., Holtz, F., Scaillet, B., Bourdier, J.-L. and Traineau, H. (1999) Effects of $\mathrm{fO}_{2}$ and $\mathrm{H}_{2} \mathrm{O}$ on andesite phase relations between 2 and 4 kbar. J. Geophys. Res. 104, $29453-29470$.

Mavrogenes, J.A. and O'Neill, H.St.C. (1999) The relative effects of pressure, temperature and oxygen fugacity on the solubility of sulfide in mafic magmas. Geochim. Cosmochim. Acta 63, 1173-1180.

Moretti, R. and Baker, D.R. (2008) Modeling the interplay of $f \mathrm{O}_{2}$ and $f \mathrm{~S}_{2}$ along the FeSsilicate melt equilibrium. Chem. Geol. 256, 286-298.

Nakamura, M. and Watson, E.B. (2001) Experimental study of aqueous fluid infiltration into quartzite: implications for the kinetics of fluid redistribution and grain growth driven by interfacial energy reduction. Geofluids 1, 73-89. 
Ohmoto, H. and Kerrick, D.M. (1977) Devolatilisation equilibria in graphitic systems. Am. J. Science 277, 1013-1044.

Polvé, M., Maury, R.C., Jégo, S., Bellon, H., Margoum, A., Yumul Jr., G.P., Payot, B., Tamayo Jr., R.A. and Cotten, J. (2007) Temporal geochemical evolution of Neogene magmatism in the Baguio gold-copper mining district (Northern Luzon, Philippines). Resource Geol. 57, 197-218.

Pownceby, M.I. and O'Neill, H.St.C. (1994) Thermodynamic data from redox reactions at high temperatures. III. Activity-composition relations in Ni-Pd alloys from EMF measurements at $850-1250 \mathrm{~K}$, and calibration of the $\mathrm{NiO}+\mathrm{Ni}-\mathrm{Pd}$ assemblage as a redox sensor. Contrib. Mineral. Petrol. 116, 327-339.

Prouteau, G. and Scaillet, B. (2003) Experimental constraints on the origin of the 1991 Pinatubo dacite. J. Petrol., 44, 2203-2241.

Prouteau, G., Maury, R.C., Sajona, F.G., Cotton, J. and Joron, J.-L. (2000) Behaviour of Niobium, Tantalum and other high field strength elements in adakites and related lavas from the Philippines. Island Arc 9, 487-498.

Rapp, R.P. and Watson, E.B. (1995) Dehydration melting of metabasalt at 8-32 kbar: Implications for continental growth and crust-mantle recycling. J. Petrol. 36, 891-931.

Ratajeski, K. and Sisson, T.W. (1999) Loss of iron to gold capsules in rock-melting experiments. Am. Mineral. 84, 1521-1527.

Richards, J.P. and Kerrich, R. (2007) Special paper: Adakite-like rocks: Their diverse origins and questionable role in metallogenesis. Econ. Geol. 102, 537-576.

Robie, R.A., Hemingway, B.S., Fisher, J.R. (1978) Thermodynamic properties of minerals and related substances at $198.15 \mathrm{~K}$ and 1 bar $\left(10^{5}\right.$ Pascals $)$ pressure and at higher 48 
temperature. Geol. Surv. Bull. 1452, 456.

Rose-Weston, L., Brenan, J.M., Fei, Y., Secco, R.A. and Frost, D. (2009) Effect of pressure, temperature, and oxygen fugacity on the metal-silicate partitioning of $\mathrm{Te}, \mathrm{Se}$, and $\mathrm{S}$ : Implications for earth differentiation. Geochim. Cosmochim. Acta 73, 4598-4615.

Sajona, F.G. and Maury, R.C. (1998) Association of adakites with gold and copper mineralization in the Philippines. C. R. Acad. Sci. Paris, Earth planet. Sci. 326, 27-34.

Scaillet, B., Pichavant, M., Roux, J., Humbert, G. and Lefevre, A. (1992) Improvements of the Shaw membrane technique for measurement and control of $\mathrm{fH}_{2}$ at high temperatures and pressures. Am. Mineral. 77, 647-655.

Scaillet, B., Pichavant, M., Roux, J. (1995) Experimental crystallisation of leucogranite magmas. J. Petrol. 36, 663-705.

Schmidt, B.C., Holtz, F., Scaillet, B. and Pichavant, M. (1997) The influence of $\mathrm{H}_{2} \mathrm{O}-\mathrm{H}_{2}$ fluids and redox conditions on melting temperatures in the haplogranite system. Contrib. Mineral. Petrol. 126, 386-400.

Sen, C. and Dunn, T. (1994) Dehydration melting of a basaltic composition amphibolite at 1.5 and 2.0 GPa: implications for the origin of adakites. Contrib. Mineral. Petrol. 117, 394409.

Sillitoe, R.H. (1997) Characteristics and controls of the largest porphyry copper-gold and epithermal gold deposits in the circum-Pacific region. Aust. J. Earth Sci. 44, 373-388.

Simon, A.C., Pettke, T., Candela, P.A., Piccoli, P.M. and Heinrich, C.A. (2003) Experimental determination of $\mathrm{Au}$ solubility in rhyolite melt and magnetite: Constraints on magmatic $\mathrm{Au}$ budgets. Am. Miner. 88, 1644-1651.

Simon, A.C., Frank, M.R., Pettke, T., Candela, P.A., Piccoli, P.M. and Heinrich, C.A. (2005) Gold partitioning in melt-vapor-brine systems. Geochim. Cosmochim. Acta 69, 3321- 
3335.

Simon, A.C., Pettke, T., Candela, P.A., Piccoli, P.M. and Heinrich, C.A. (2007) The partitioning behaviour of $\mathrm{As}$ and $\mathrm{Au}$ in $\mathrm{S}$-free and S-bearing magmatic assemblages. Geochim. Cosmochim. Acta 71, 1764-1782.

Simon, A.C., Candela, P.A., Piccoli, P.M., Mengason, M. and Englander, L. (2008) The effect of crystal-melt partitioning on the budgets of $\mathrm{Cu}, \mathrm{Au}$, and Ag. Am. Mineral. 93, 1437 1448 .

Sun, W., Arculus, R.J., Kamenetsky, V.S. and Binns, R.A. (2004) Release of gold-bearing fluids in convergent margin magmas prompted by magnetite crystallization. Nature, 431, 975-978.

Taylor, J.R., Wall, V.J. and Pownceby, M.I. (1992) The calibration and application of accurate redox sensors. Am. Mineral. 77, 284-295.

Truckenbrodt, J. and Johannes, W. (1999) $\mathrm{H}_{2} \mathrm{O}$ loss during piston-cylinder experiments. Am. Mineral. 84, 1333-1335.

Ulrich, T., Günther, D. and Heinrich, C.A. (1999) Gold concentrations of magmatic brines and the metal budget of porphyry copper deposits. Nature 399, 676-679.

Watson, E.B. (1994) Diffusion in volatile-bearing magmas. Rev. Miner. 30, 371-411.

Winther, K.T., Watson, E.B. and Korenowski, G.M. (1998) Magmatic sulfur compounds and sulfur diffusion in albite melt at $1 \mathrm{GPa}$ and $1300-1500{ }^{\circ} \mathrm{C}$. Am. Mineral. 83, 1141-1151.

Yang, X.-M. (2012) Sulphur solubility in felsic magmas: Implications for genesis of intrusion-related gold mineralization. Geoscience Canada 39, 17-32.

Yumul, G.P., Jr., Dimalanta, C.B., Bellon, H., Faustino, D.V., De Jesus, J.V., Tamayo, R.A., 50 Jr. and Jumawan, F.T. (2000) Adakitic lavas in the Central Luzon back-arc region, 
Philippines: Lower crust partial melting products ? Island Arc 9, 499-512.

Zajacz, Z., Seo, J.H., Candela, P.A., Piccoli, P.M., Heinrich, C.A. and Guillong, M. (2010) Alkali metals control the release of gold from volatile-rich magmas. Earth Planet. Sci. Lett. 297, 50-56.

Zajacz, Z., Candela, P.A., Piccoli, P.M., Wälle, M. and Sanchez-Valle, C. (2012) Gold and copper in volatile saturated mafic to intermediate magmas: Solubilities, partitioning, and implications for ore deposit formation. Geochim. Cosmochim. Acta 91, 140-159.

Zajacz, Z., Candela, P.A., Piccoli, P.M., Sanchez-Valle, C. and Wälle, M. (2013) Solubility and partitioning behavior of $\mathrm{Au}, \mathrm{Cu}, \mathrm{Ag}$ and reduced $\mathrm{S}$ in magmas. Geochim. Cosmochim. Acta 112, 288-304.

Zajacz, Z. (2015) The effect of melt composition on the partitioning of oxidized sulfur between silicate melts and magmatic volatiles. Geochim. Cosmochim. Acta 158, 223-244. Zellmer, G.F., Iizuka, Y., Miyoshi, M., Tamura, Y. and Tatsumi, Y. (2012) Lower crustal $\mathrm{H}_{2} \mathrm{O}$ controls on the formation of adakitic melts. Geology 40, 487-490.

\section{FIGURE CAPTIONS}

Figure 1: SEM-EDS shots of representative experimental sulfur-free $(a, b, c)$ and sulfur-bearing (e,d,f) charges. a) Crystal-free, bubble-bearing silicate melt quenched to glass (Au13-1); b) Typical phase assemblage of most of S-free charges, i.e. $<10 \mathrm{wt} \%$ silicate mineral phase + glass. Here, the mineral phase is amphibole (Au14-2); c) Detail of Au03-2 charge showing 
small clusters of tiny magnetite crystals surrounded by quench crystals of cpx (the scale bar represents $50 \mu \mathrm{m}$ ); d) Typical phase assemblage of most of S-bearing charges, showing cpx and/or amphibole + pyrrhotite crystals and minor vapour phase in quenched silicate liquid. The large hole in the middle of the picture was drilled by the laser beam during ICPMS analyses. Here, in Au10-2, both silicate species are present, as seen in the next shot (e), detail of the Au10-2 charge, which illustrates a close and particular textural association between cpx and amphibole: very small $(<10 \mu \mathrm{m})$ and slightly darker crystals of amphibole grow on both extremities of larger cpx crystals; f) Detail of Au11-1 charge showing a progressive inclusion of sulfides by a growing cpx crystal.

Figure 2: Concentration of sulfur (in $\mathrm{ppm}$ ) in experimental melts quenched to glass at $\sim 1000^{\circ} \mathrm{C}, 0.9$ and $1.4 \mathrm{GPa}$, (a) as a function of $\log \left(f \mathrm{O}_{2}\right)$ expressed relative to the $\mathrm{Ni}-\mathrm{NiO}$ buffer (i.e., $\triangle \mathrm{NNO}=0$, calculated at the respective $\mathrm{P}$ and $\mathrm{T}$ of each study); (b) as a function of $\log \left(f S_{2}\right)$ calculated from the model of Liu et al. (2007) (L07). See text for calculation details. Error bars, $\pm 1 \sigma$, are based on replicate microprobe analyses. Data at 0.4 GPa from Jégo and Pichavant (2012) (JP12), at 0.2 GPa from Botcharnikov et al. (2010) (B10) and Botcharnikov et al. (2011) (B11), and at $0.12 \mathrm{GPa}$ from Simon et al. (2007) (S07) are shown for comparison.

Figure 3: Concentration of gold (in ppb) in sulfur-free experimental melts quenched to glass as a function of $\log \left(f \mathrm{O}_{2}\right)$ expressed relative to the $\mathrm{Ni}-\mathrm{NiO}$ buffer (i.e., $\Delta \mathrm{NNO}=0$, calculated at the respective $\mathrm{P}$ and $\mathrm{T}$ of each study). Error bars, $\pm 1 \sigma$, based on replicate ICP-MS analyses, are within the size of the symbols. Data at $0.4 \mathrm{GPa}$ from Jégo et al. (2010) (J10), at $0.2 \mathrm{GPa}$ 52 
from Botcharnikov et al. (2011) (B11), and at 1 atm from Borisov and Palme (1996) (BP96) are shown for comparison. All lines are exponential fits of the data points. (b) Concentration of gold (in ppb) in sulfur-free experimental melts quenched to glass at $\sim 1000^{\circ} \mathrm{C}$ as a function of pressure expressed in kbar, including the data of Jégo et al. (2010). The symbols distinguish the data according to their starting composition and $f \mathrm{O}_{2}$ range.

Figure 4: Concentration of gold (in ppb) in sulfur-bearing experimental melts quenched to glass, (a) as a function of $\log \left(f \mathrm{O}_{2}\right)$ expressed relative to the $\mathrm{Ni}-\mathrm{NiO}$ buffer (i.e., $\Delta \mathrm{NNO}=0$, calculated at the respective $\mathrm{P}$ and $\mathrm{T}$ of each study); (b) as a function of $\log \left(f \mathrm{~S}_{2}\right)$ calculated from the model of Liu et al. (2007) (L07). See text for calculation details. Error bars, $\pm 1 \sigma$, are based on replicate ICP-MS analyses. Data at 0.4 GPa from Jégo and Pichavant (2012) (JP12), at 0.2 GPa from Botcharnikov et al. (2010) (B10) and Botcharnikov et al. (2011) (B11), and at $0.12 \mathrm{GPa}$ from Simon et al. (2007) (S07) are shown for comparison.

Figure 5: (a) Concentration of gold (in $\mathrm{ppb}$ ) in sulfur-bearing experimental melts quenched to glass at $\sim 1000^{\circ} \mathrm{C}, 0.9$ and $1.4 \mathrm{GPa}$, as a function of the concentration of sulfur (in ppm) in melt. Error bars, $\pm 1 \sigma$, are based on replicate ICP-MS and microprobe analyses, respectively. Same symbols as in Fig. 4a. (b) Comparison between calculated SCSS or SCAS values and measured melt sulfur concentrations in the moderately oxidized charges of Jégo and Pichavant (2012) (JP12) at $0.4 \mathrm{GPa}$. Error bars, $\pm 1 \sigma$, are based on replicate microprobe analyses. See text for details.

Figure 6: Interpretative diagrams of (a) sulfur solubility (in ppm) and (b) gold solubility (in $\mathrm{ppb}$ ) as a function of $f \mathrm{O}_{2}$ expressed relative to the $\mathrm{Ni}-\mathrm{NiO}$ buffer (i.e., $\Delta \mathrm{NNO}=0$, calculated at 
the respective $\mathrm{P}$ and $\mathrm{T}$ of each study). Data at $0.4 \mathrm{GPa}$ from Jégo and Pichavant (2012) (JP12), and at 0.2 GPa from Botcharnikov et al. (2011) (B11) are plotted for comparison with data of the present study. The thin black dashed lines show the evolution of sulfur and gold concentrations in melt with increasing $\mathrm{fO}_{2}$ in moderately and very oxidizing conditions, and the red dashed lines mark the shift of the sulfide-sulfate transition towards more oxidizing conditions when pressure and degree of melt polymerization increase. The thick black dashed lines show the steep increase of sulfur and gold concentrations in reducing conditions owing to the influence of other parameters $\left(\mathrm{X}_{\mathrm{FeO}}, a \mathrm{H}_{2} \mathrm{O}\right.$, melt composition). Note that the two Bal2 charges at 1.4 GPa plot out of the diagram in panel (b), at very high gold concentrations. See text for explanations. 


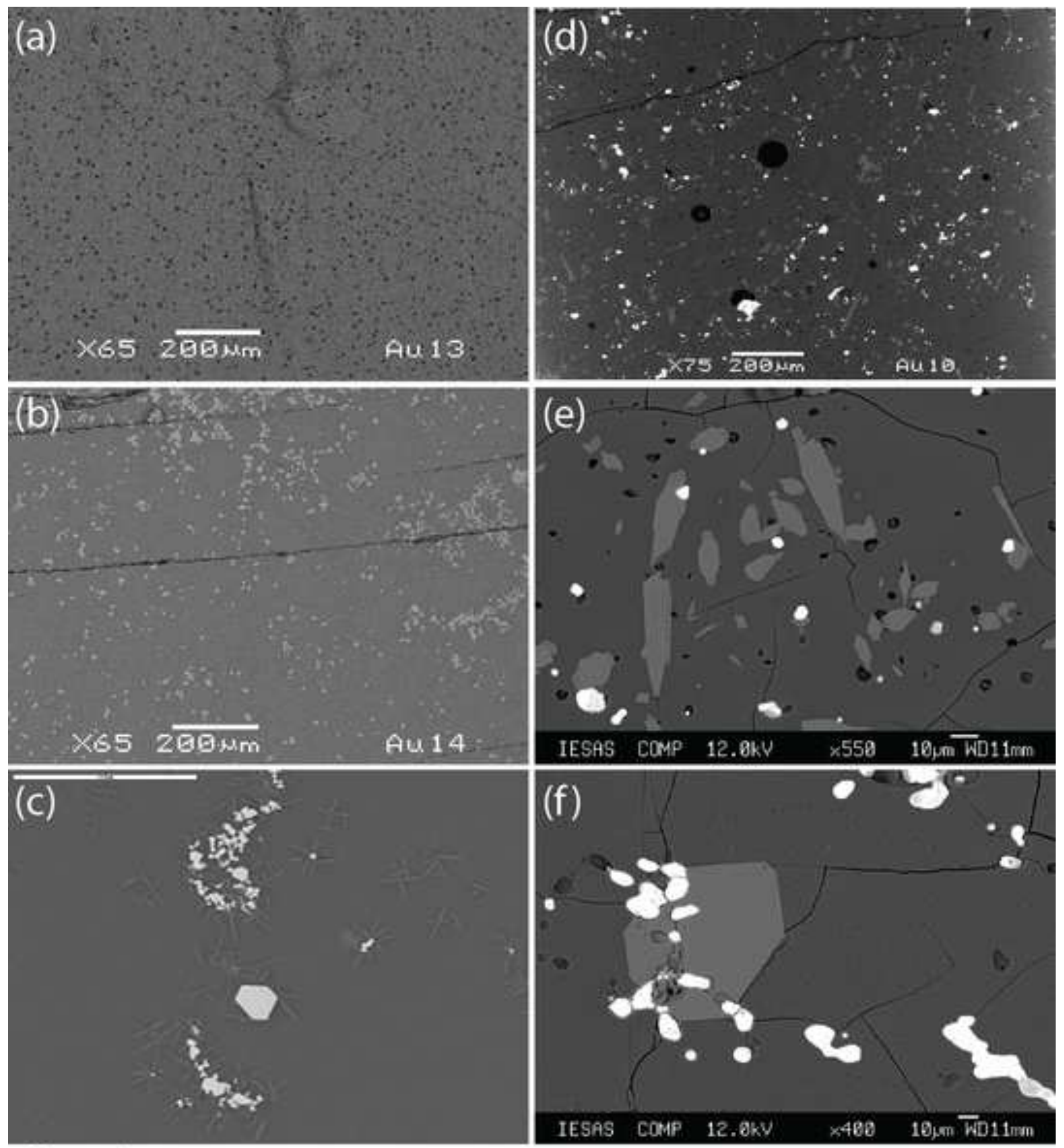

Figure 1 


\section{ACCEPTED MANUSCRIPT}
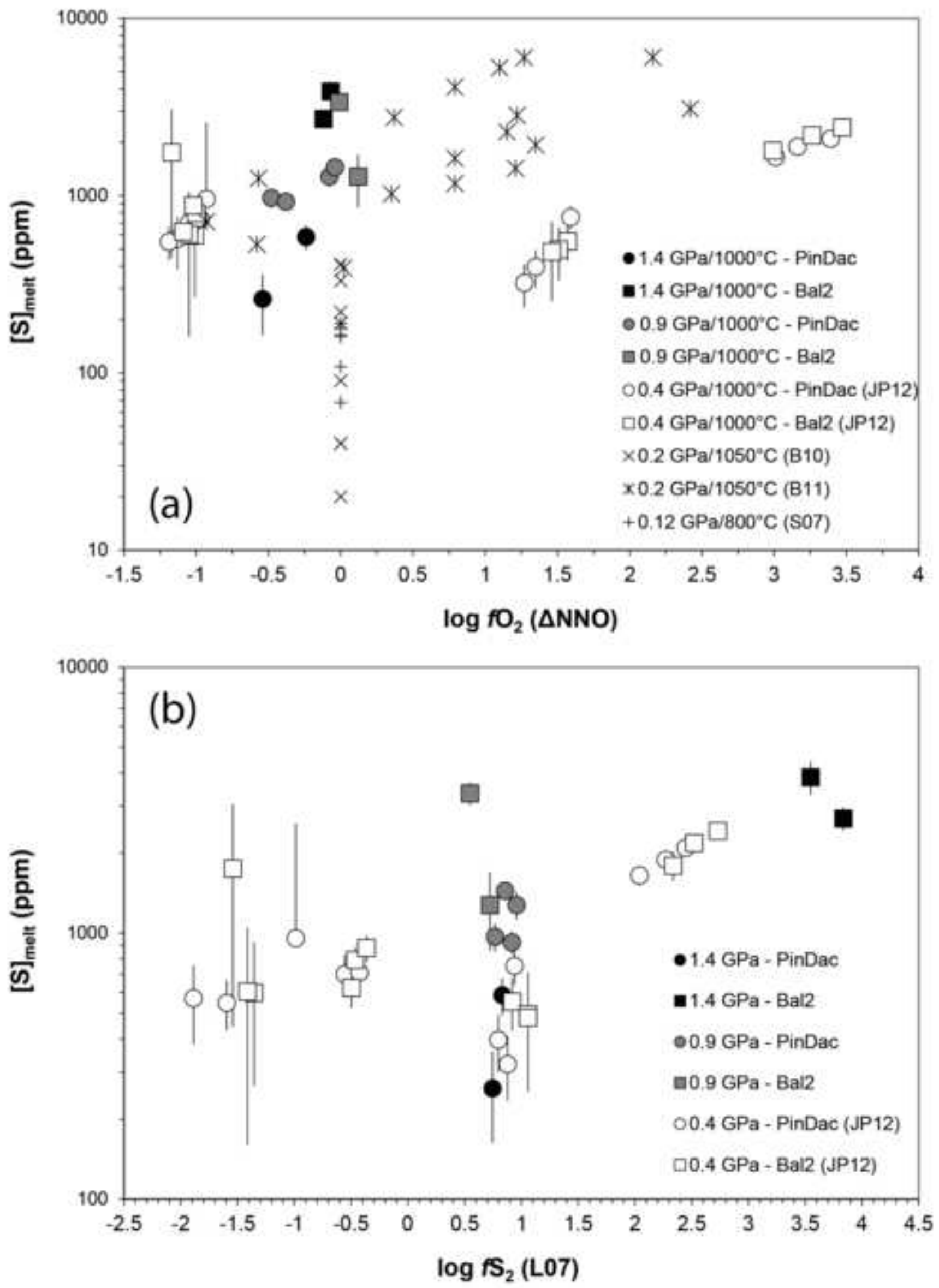


\section{ACCEPTED MANUSCRIPT}
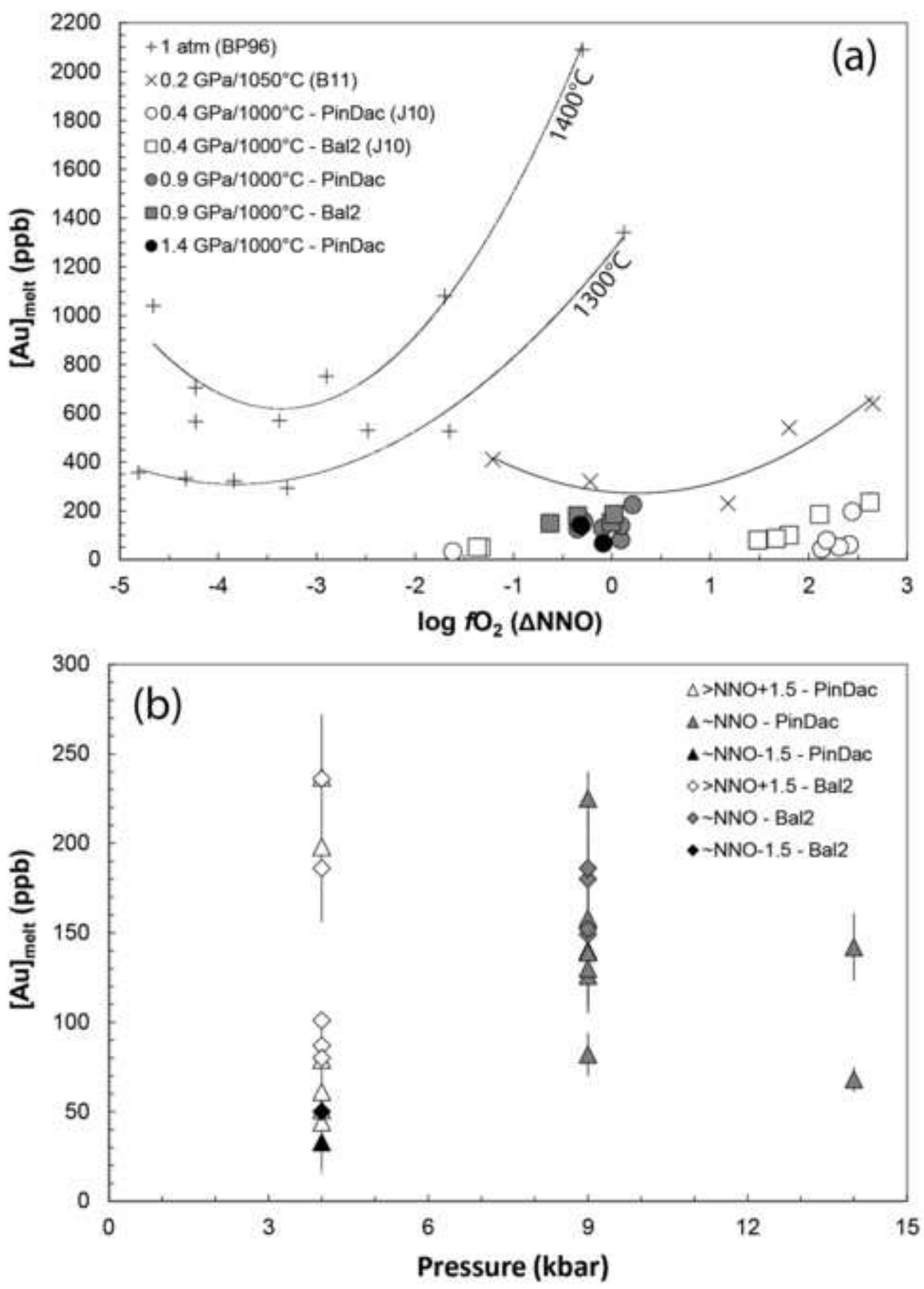

Figure 3 


\section{ACCEPTED MANUSCRIPT}
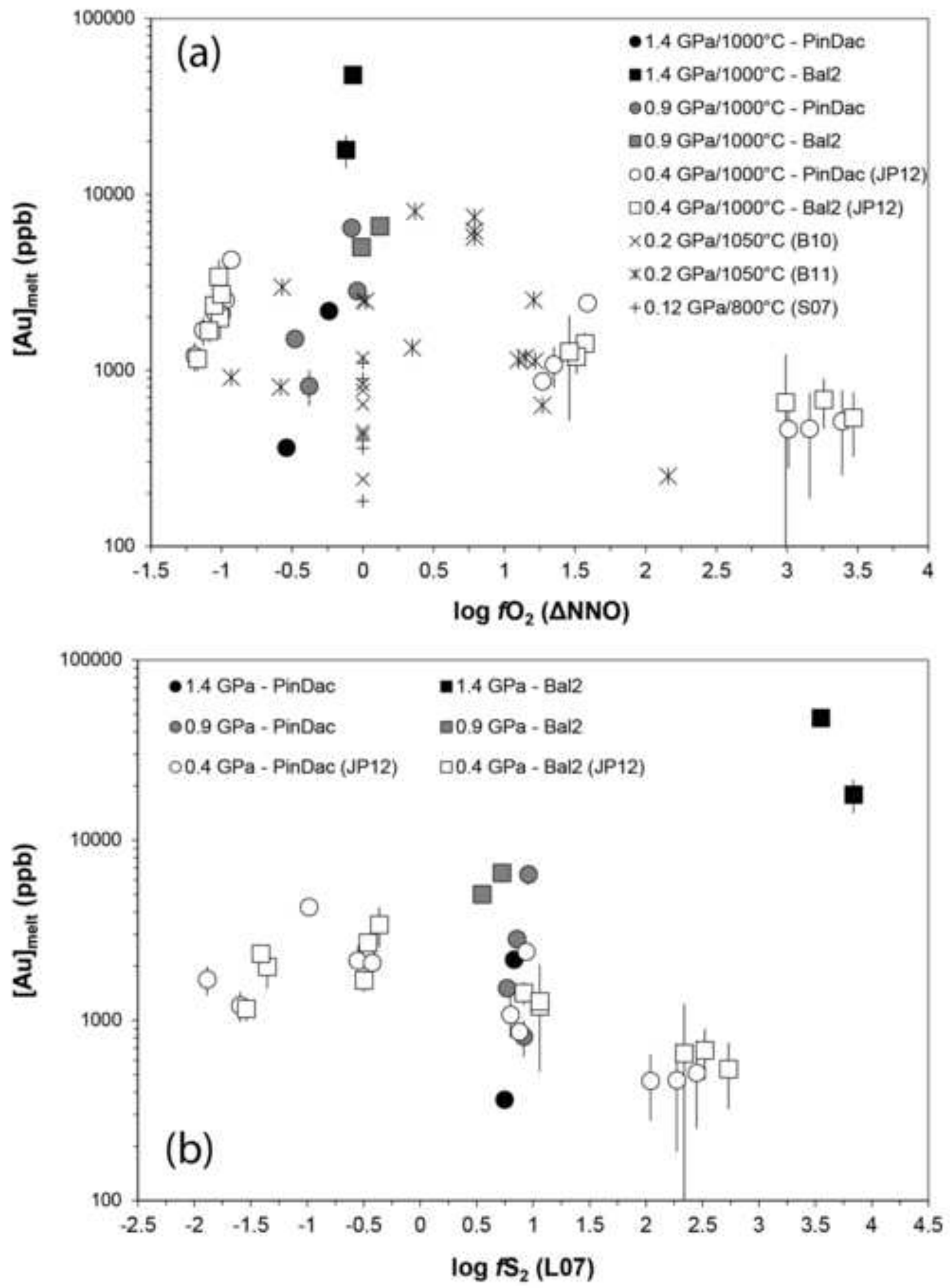

Figure 4 


\section{ACCEPTED MANUSCRIPT}
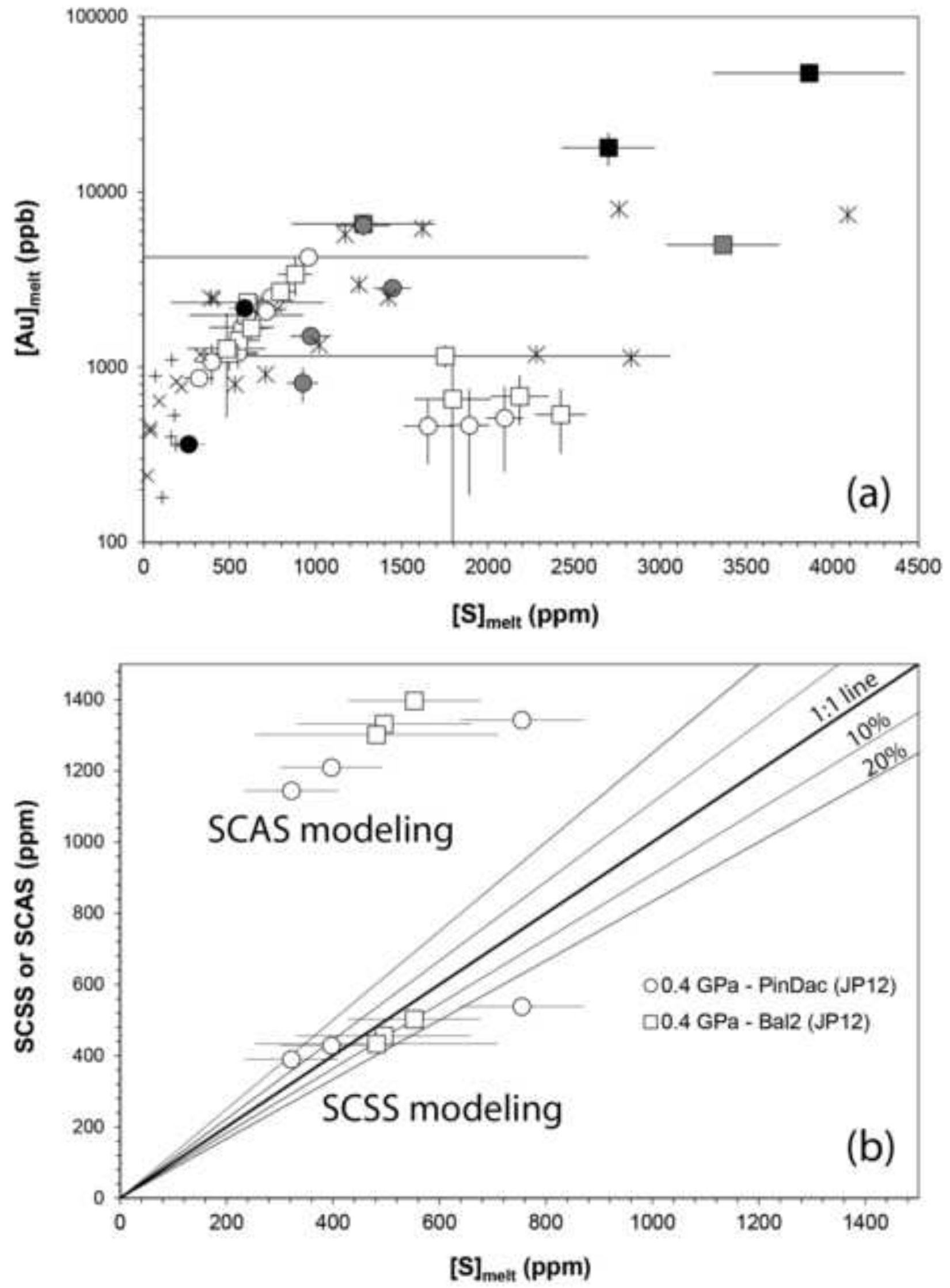

Figure 5 


\section{ACCEPTED MANUSCRIPT}
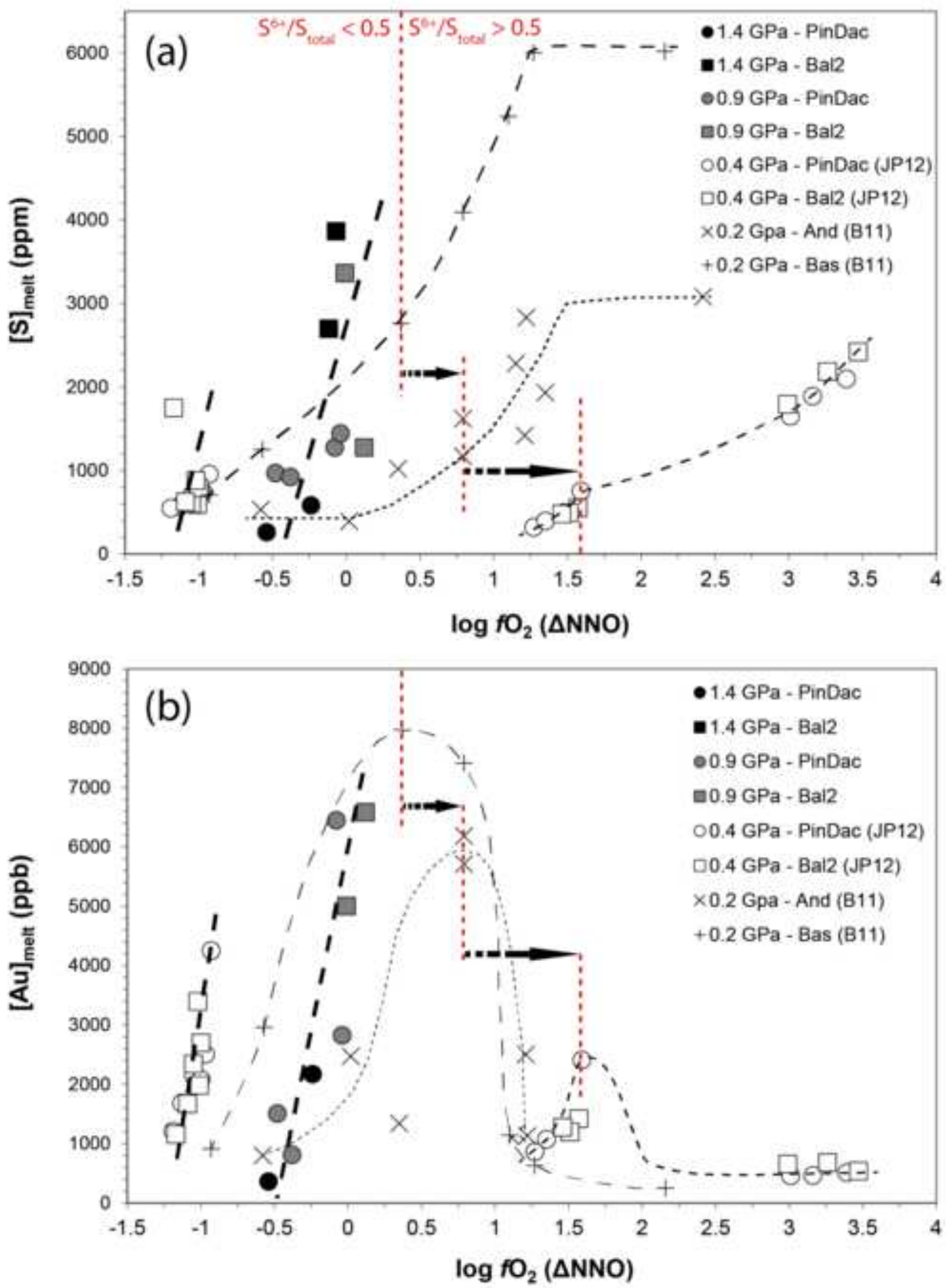

Flgure 6 
Table 1

Composition of starting materials

\begin{tabular}{|c|c|c|}
\hline Sample & Bal 2 & Pin Dac \\
\hline $\mathrm{n}$ & 17 & 16 \\
\hline $\mathrm{SiO}_{2}(\mathrm{wt} \%)$ & $65.09(0.39)$ & $64.45(0.55)$ \\
\hline $\mathrm{TiO}_{2}$ & $0.35(0.06)$ & $0.50(0.06)$ \\
\hline $\mathrm{Al}_{2} \mathrm{O}_{3}$ & $15.60(0.19)$ & $15.72(0.21)$ \\
\hline $\mathrm{Cr}_{2} \mathrm{O}_{3}$ & $0.06(0.06)$ & $0.04(0.06)$ \\
\hline $\mathrm{FeO}$ & $2.93(0.16)$ & $3.96(0.20)$ \\
\hline $\mathrm{MnO}$ & $0.06(0.06)$ & $0.11(0.10)$ \\
\hline $\mathrm{MgO}$ & $2.72(0.11)$ & $2.32(0.08)$ \\
\hline $\mathrm{CaO}$ & $4.45(0.10)$ & $4.99(0.10)$ \\
\hline $\mathrm{Na}_{2} \mathrm{O}$ & $4.78(0.09)$ & $4.29(0.10)$ \\
\hline $\mathrm{K}_{2} \mathrm{O}$ & $1.83(0.05)$ & $1.54(0.06)$ \\
\hline Total & $97.86(0.44)$ & $97.94(0.58)$ \\
\hline $\mathrm{Sr} / \mathrm{Y}$ & 197.8 & 42.4 \\
\hline $\mathrm{Au}(\mathrm{ppb})$ & 38 & 12 \\
\hline $\mathrm{S}(\mathrm{ppm})$ & bdl & bdl \\
\hline
\end{tabular}

Major elements and sulfur in anhydrous double-melting quenched glasses (starting materials; see text) were measured by EPMA in Taipei, Taiwan (IES, Academia Sinica). Oxides and totals are in $w t \%$, with uncertainties presented as once the standard error of the mean $( \pm 1 \sigma)$ for the $\mathrm{n}$ replicate measurements. Bulk Au concentrations (in ppb) in natural samples were determined by ICP-MS in Toulouse, France, using the methods described by Aries et al. (2000). Sr/Y ratios of bulk natural samples (from Jégo et al., 2010) give information about the adakitic imprint of the starting materials. bdl: below detection limit (here, <30 ppm); see text for details. 
Table 2

Summary of experimental data

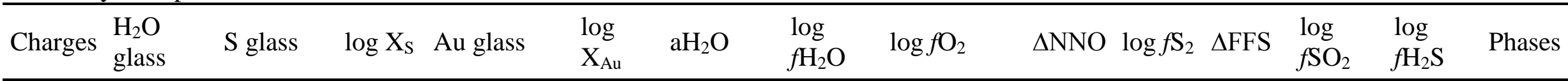

Run No. 1 : Composition Bal2, $\mathrm{P}=0.9 \mathrm{GPa}, \mathrm{T}=1000^{\circ} \mathrm{C}, f \mathrm{H}_{2}=83.9 \mathrm{bar}, \mathrm{X}_{\mathrm{Co}}=0.244, \mathrm{t}=96 \mathrm{~h}$

\begin{tabular}{|c|c|c|c|c|c|c|c|c|c|}
\hline $\mathrm{Au} 01-3$ & $5.4(0.8)$ & - & $149(40)$ & -7.283 & $\begin{array}{l}0.41 \\
(0.07) \\
0.56\end{array}$ & 3.78 & $\begin{array}{l}-10.79 \\
(0.16) \\
-10.51\end{array}$ & -0.63 & $\mathrm{gl} ; \mathrm{amph} ; \mathrm{cpx} ; \mathrm{ol} ; \mathrm{ox}$ \\
\hline $\mathrm{Au} 01-4$ & $7.2(0.8)$ & - & $180(38)$ & -7.190 & $(0.06)$ & 3.91 & $(0.10)$ & -0.35 & $\mathrm{gl}$; cpx; amph; ol; ox \\
\hline
\end{tabular}

Run No. 2 : Composition Pin Dac, $\mathrm{P}=0.9 \mathrm{GPa}, \mathrm{T}=950^{\circ} \mathrm{C}, f \mathrm{H}_{2}=87.1 \mathrm{bar}, \mathrm{X}_{\mathrm{Co}}=0.263, \mathrm{t}=46 \mathrm{~h}$

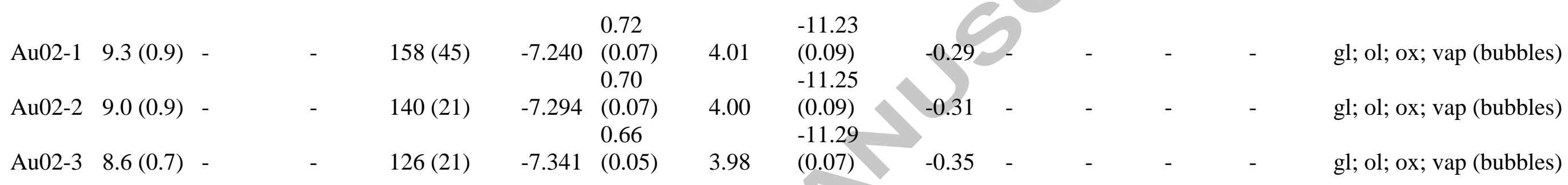

Run No. 3 : Composition Bal2, $\mathrm{P}=0.9 \mathrm{GPa}, \mathrm{T}=1000^{\circ} \mathrm{C}, f \mathrm{H}_{2}=83.9 \mathrm{bar}, \mathrm{X}_{\mathrm{Co}}=0.244, \mathrm{t}=96 \mathrm{~h}$

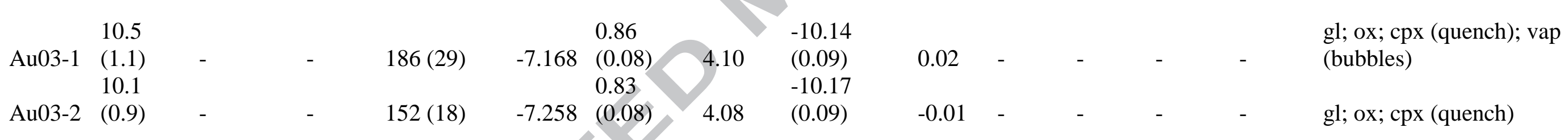

Run No. 9 : Composition Pin Dac, $\mathrm{P}=0.9 \mathrm{GPa}, \mathrm{T}=1000^{\circ} \mathrm{C}, \mathrm{fH}_{2}=76.9 \mathrm{bar}, \mathrm{X}_{\mathrm{Co}}=0.235, \mathrm{t}=80 \mathrm{~h}$

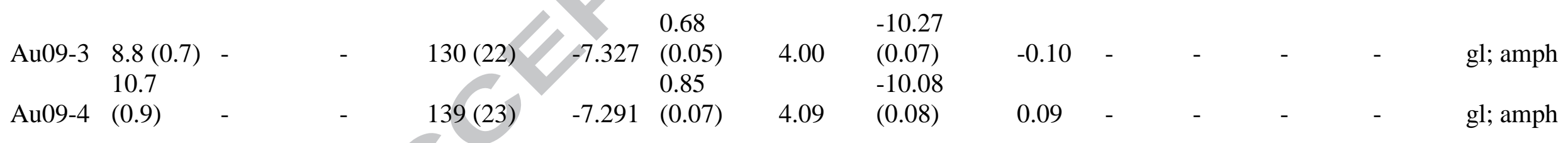


Run No. 13 : Composition Pin Dac, $\mathrm{P}=0.9 \mathrm{GPa}, \mathrm{T}=975^{\circ} \mathrm{C}, \mathrm{fH}_{2}=65.9$ bar, $\mathrm{X}_{\mathrm{Co}}=0.227, \mathrm{t}=96 \mathrm{~h}$

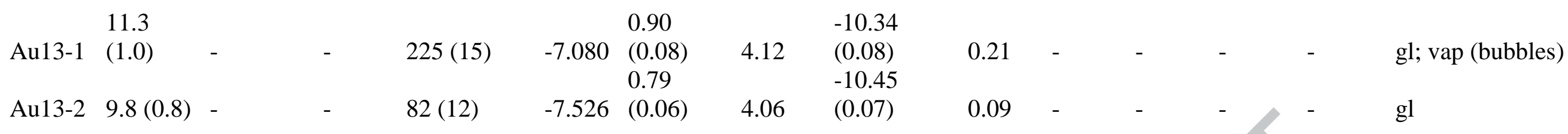

Run No. 14 : Composition Pin Dac, $\mathrm{P}=1.4 \mathrm{GPa}, \mathrm{T}=975^{\circ} \mathrm{C}, f \mathrm{H}_{2}=187.6 \mathrm{bar}, \mathrm{X}_{\mathrm{Co}}=0.227, \mathrm{t}=70 \mathrm{~h}$

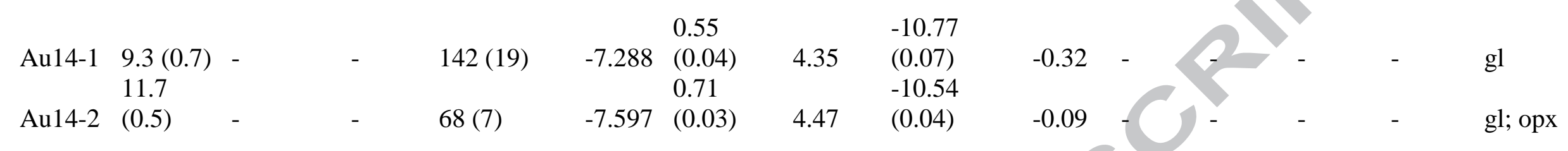

Run No. 10 : Composition Pin Dac, $\mathrm{P}=0.9 \mathrm{GPa}, \mathrm{T}=1000^{\circ} \mathrm{C}, \mathrm{fH}_{2}=111.5 \mathrm{bar}, \mathrm{X}_{\mathrm{Co}}=0.276, \mathrm{t}=40 \mathrm{~h}$

\begin{tabular}{|c|c|c|c|c|c|c|c|c|c|c|c|c|c|c|}
\hline Au10-1 & $8.5(0.7)$ & $970(118)$ & -5.152 & 1508 (118) & -6.267 & $\begin{array}{l}0.64 \\
(0.06) \\
0.72\end{array}$ & 3.97 & $\begin{array}{l}-10.64 \\
(0.08) \\
-10.54\end{array}$ & -0.48 & 0.77 & 6.79 & 0.83 & 3.53 & gl; cpx; amph; pyrrh; vap \\
\hline Au10-2 & $9.4(0.8)$ & $924(89)$ & -5.183 & $813(186)$ & -6.529 & $(0.06)$ & 4.03 & $(0.08)$ & -0.38 & 0.92 & 6.94 & 1.00 & 3.62 & gl; cpx; amph; pyrrh; vap \\
\hline
\end{tabular}

Run No. 11 : Composition Pin Dac, $\mathrm{P}=0.9 \mathrm{GPa}, \mathrm{T}=975^{\circ} \mathrm{C}, \mathrm{fH}_{2}=76.5 \mathrm{bar}, \mathrm{X}_{\mathrm{Co}}=0.242, \mathrm{t}=96 \mathrm{~h}$

\begin{tabular}{|c|c|c|c|c|c|c|c|c|c|c|c|c|c|}
\hline Au11-1 & $9.9(0.9)$ & $\begin{array}{l}1444 \\
(107) \\
1276\end{array}$ & -5.042 & $2825(220)$ & -5.988 & 4.06 & $\begin{array}{l}-10.58 \\
(0.08) \\
-10.63\end{array}$ & -0.04 & 0.86 & 7.11 & 1.23 & 3.51 & gl; cpx; pyrrh; vap \\
\hline Au11-2 & $9.4(1.0)$ & $(154)$ & -5.073 & $6446(813)$ & -5.632 & 4.03 & $(0.09)$ & -0.08 & 0.96 & 7.21 & 1.23 & 3.55 & gl; pyrrh; vap (bubbles) \\
\hline
\end{tabular}

Run No. 15 : Composition Pin Dac, $\mathrm{P}=1.4 \mathrm{GPa}, \mathrm{T}=975^{\circ} \mathrm{C}, f \mathrm{H}_{2}=213.6$ bar, $\mathrm{X}_{\mathrm{Co}}=0.240, \mathrm{t}=96 \mathrm{~h}$

\begin{tabular}{|c|c|c|c|c|c|c|c|c|c|c|c|c|c|c|}
\hline Au15-1 & $\begin{array}{l}11.3 \\
(0.9)\end{array}$ & $585(93)$ & -5.439 & $2174(79)$ & -6.095 & $\begin{array}{l}0.69 \\
(0.05)\end{array}$ & 4.45 & $\begin{array}{l}-10.69 \\
(0.07)\end{array}$ & -0.24 & 0.83 & 6.62 & 1.10 & 3.94 & gl; amph; pyrrh; vap \\
\hline Au15-2 & $8.2(0.7)$ & $261(98)$ & -5.808 & $363(3)$ & -6.886 & 0.48 & 4.30 & -10.99 & -0.54 & 0.75 & 6.53 & 0.76 & 3.90 & gl; amph; pyrrh; vap \\
\hline
\end{tabular}


Run No. 16 : Composition Bal2, $\mathrm{P}=0.9 \mathrm{GPa}, \mathrm{T}=975^{\circ} \mathrm{C}, f \mathrm{H}_{2}=78.0 \mathrm{bar}, \mathrm{X}_{\mathrm{Co}}=0.244, \mathrm{t}=106 \mathrm{~h}$

\begin{tabular}{|c|c|c|c|c|c|c|c|c|c|c|c|c|c|c|}
\hline Au16-1 & $\begin{array}{l}10.3 \\
(0.9)\end{array}$ & $\begin{array}{l}3364 \\
(328)\end{array}$ & -4.761 & $5004(444)$ & -5.738 & $\begin{array}{l}0.82 \\
(0.07)\end{array}$ & 4.08 & $\begin{array}{l}-10.56 \\
(0.07)\end{array}$ & -0.01 & 0.55 & 6.80 & 1.09 & 3.36 & gl; pyrrh; vap (bubbles) \\
\hline & 12.4 & 1276 & & & & 0.96 & & -10.42 & & & & & & \\
\hline u16-2 & $(0.8)$ & (417) & -5.154 & $6583(568)$ & -5.607 & $(0.06)$ & 4.15 & $(0.06)$ & 0.12 & 0.72 & 6.97 & 1.32 & 3.45 & gl; amph; pyrrh; vap \\
\hline
\end{tabular}

Run No. 17 : Composition Bal2, $\mathrm{P}=1.4 \mathrm{GPa}, \mathrm{T}=975^{\circ} \mathrm{C}, f \mathrm{H}_{2}=222.0$ bar, $\mathrm{X}_{\mathrm{Co}}=0.244, \mathrm{t}=96 \mathrm{~h}$

\begin{tabular}{|c|c|c|c|c|c|c|c|c|c|c|c|c|c|c|}
\hline Au17-1 & $\begin{array}{l}14.8 \\
(0.6)\end{array}$ & $\begin{array}{l}3865 \\
(556)\end{array}$ & -4.735 & $\begin{array}{l}47771 \\
(2250)\end{array}$ & -4.732 & $\begin{array}{l}0.86 \\
(0.03)\end{array}$ & 4.55 & $\begin{array}{l}-10.52 \\
(0.03)\end{array}$ & -0.07 & 3.55 & 9.33 & 2.63 & 5.31 & gl; micas; vap \\
\hline & 13.8 & 2700 & & 17896 & & 0.81 & & -10.57 & & & & & & \\
\hline & $(1.0)$ & $(272)$ & -4.887 & (3801) & -5.161 & $(0.06)$ & 4.53 & (0.06) & & .84 & 9.62 & 2.73 & 5.46 & gl; micas; vap \\
\hline
\end{tabular}

$\mathrm{H} 2 \mathrm{O}$ glass: water content in silicate glass in wt. $\%( \pm 1 \sigma)$; S glass: sulfur content in silicate glass in ppm $( \pm 1 \sigma)$; log XS: logarithm of sulfur mole fraction in silicate glass; Au glass: gold content in silicate glass in ppb $( \pm 1 \sigma)$; $\log \mathrm{XAu}$ : logarithm of the gold mole fraction in silicate glass; aH2O and fH2O: water activity of the charge $( \pm 1 \sigma)$ and corresponding water fugacity, respectively; log fO2: oxygen fugacity of the charge $( \pm 1 \sigma)$. $\Delta \mathrm{NNO}$ : difference between log fO2 of the charge and $\log \mathrm{fO} 2$ of the $\mathrm{Ni}-\mathrm{NiO}$ equilibrium at the same pressure and temperature. $\log \mathrm{fS} 2$ in sulfur-bearing charges was calculated from the expression of Liu et al. (2007). $\triangle \mathrm{FFS}$ : difference between $\log$ fS2 of the charge and $\log$ fS2 of the iron-pyrrhotite equilibrium at the same pressure and temperature. log fSO2 and $\log \mathrm{fH} 2 \mathrm{~S}$ were obtained by using the equilibrium constants of Ohmoto and Kerrick (1977). fH2 values were calculated from the fO2 inside the sensor capsule (Taylor et al., 1992), taking $\mathrm{fH} 2 \mathrm{O}=\mathrm{f}^{\circ} \mathrm{H} 2 \mathrm{O}$. XCo values are the average proportions of Co in the solid sensor alloys. $\mathrm{t}$ is the experimental duration in hours. gl: glass; pyrrh: pyrrhotite; cpx: clinopyroxene; amph: amphibole; ox: oxide; opx: orthopyroxene; ol: olivine; vap: vapour phase. See text for details. 